This item was submitted to Loughborough's Research Repository by the author.

Items in Figshare are protected by copyright, with all rights reserved, unless otherwise indicated.

\title{
Improvement of mechanical-antibacterial performances of AR/PMMA with TiO2 and HPQM treated by N-2(aminoethyl)-3-aminopropyl trimethoxysilane
}

\author{
PLEASE CITE THE PUBLISHED VERSION
}

https://doi.org/10.1177/0731684420975199

\section{PUBLISHER}

Sage

VERSION

AM (Accepted Manuscript)

\section{PUBLISHER STATEMENT}

This paper was accepted for publication in the journal Journal of Reinforced Plastics and Composites and the definitive published version is available at https://doi.org/10.1177/0731684420975199. Users who receive access to an article through a repository are reminded that the article is protected by copyright and reuse is restricted to non-commercial and no derivative uses. Users may also download and save a local copy of an article accessed in an institutional repository for the user's personal reference.

\section{LICENCE}

In Copyright

\section{REPOSITORY RECORD}

Tangudom, P, Nacho Martin-Fabiani-Carrato, B Prapagdee, E Wimolmala, T Markpin, and N Sombatsompop. 2020. "Improvement of Mechanical-antibacterial Performances of AR/PMMA with Tio2 and HPQM Treated by N-2(aminoethyl)-3-aminopropyl Trimethoxysilane". Loughborough University. https://hdl.handle.net/2134/13516889.v1. 
Journal of

Reinforced Plastics and Composites

\section{Improvement of mechanical-antibacterial performances of AR/PMMA with $\mathrm{TiO}_{2}$ and $\mathrm{HPQM}$ treated by N-2(aminoethyl)- 3-aminopropyl trimethoxysilane}

\begin{tabular}{|c|c|}
\hline Journal: & Journal of Reinforced Plastics and Composites \\
\hline Manuscript ID & JRP-20-0775.R1 \\
\hline Manuscript Type: & Original Article \\
\hline $\begin{array}{r}\text { Date Submitted by the } \\
\text { Author: }\end{array}$ & $\mathrm{n} / \mathrm{a}$ \\
\hline Complete List of Authors: & $\begin{array}{l}\text { Tangudom, Paveena; King Mongkut's University of Technology Thonburi, } \\
\text { Materials Technology } \\
\text { Martin-Fabiani, Ignacio ; Loughborough University, Department of } \\
\text { Materials } \\
\text { Prapagdee, Benjaphorn; Mahidol University Faculty of Environment and } \\
\text { Resource Studies, Laboratory of Environmental Biotechnology } \\
\text { Markpin, Teerasak; King Mongkut's University of Technology Thonburi, } \\
\text { Materials Technology } \\
\text { Wimolmala, Ekachai; KMUTT, Materials Technology } \\
\text { Sombatsompop, Narongrit; KMUTT, Materials Technology; KMUTT, }\end{array}$ \\
\hline Keyword: & $\begin{array}{l}\text { Acrylic rubber, Antibacterial performance, Poly (methyl methacrylate), } \\
\text { Silane coupling agent, Titanium dioxide }\end{array}$ \\
\hline Abstract: & $\begin{array}{l}\text { The mechanical and antibacterial properties of acrylic rubber/poly (methyl } \\
\text { methacrylate) (AR/PMMA) blend at } 10 \text { to } 50 \text { wt } \% \text { of AR content with } \\
\text { non-treated and treated titanium dioxide (TiO2) and 2-Hydroxypropyl-3- } \\
\text { piperazinyl-quinoline carboxylic acid methacrylate (HPQM) by N- } \\
\text { 2(aminoethyl)-3-aminopropyl trimethoxysilane were studied. The } \\
\text { antibacterial property against Escherichia coli was evaluated. The results } \\
\text { found that the mechanical properties of ARt-TiO2/PMMA and ARt- } \\
\text { HPQM/PMMA blend were higher than that of the ARTiO2/PMMA and } \\
\text { ARHPQM/PMMA blend. For antibacterial property, the ARHPQM/PMMA } \\
\text { and ARt-HPQM/PMMA blend could act as the antibacterial material, while } \\
\text { the ARTiO2/PMMA blend did not show. However, the ARt-TiO2/PMMA } \\
\text { blend could inhibit bacterial cell growth with } 10 \text { to } 30 \text { wt } \% \text { of AR content. } \\
\text { The recommended compositions of ARt-TiO2/PMMA blend, which } \\
\text { improved both mechanical and antibacterial properties, were } 10 \text { to } 30 \\
\text { wt\% of AR and were } 10 \text { to } 50 \text { wt\% of AR for ARt-HPQM/PMMA. } \\
\text { Moreover, the UV radiation increased the antibacterial properties by the } \\
\text { destruction of the interaction in treated TiO2 and HPQM and improved } \\
\text { the antibacterial performance of ARt-TiO2/PMMA and ARt-HPQM/PMMA } \\
\text { blend. }\end{array}$ \\
\hline
\end{tabular}


Revised JRP-20-775

${ }^{a}$ Polymer PROcessing and Flow (P-PROF) Research Group, Materials Technology Program, School

of Energy, Environment and Materials, King Mongkut's University of Technology Thonburi

(KMUTT), 126 Pracha-Uthit, Thungkru, Bangmod, Bangkok 10140, Thailand

16

17 Department of Materials, Loughborough University, Loughborough LE11 3TU, Leicestershire

United Kingdom

19

20 'Laboratory of Environmental Biotechnology, Faculty of Environment and Resource Studies, Mahidol

21 University, Salaya, Phutthamonthon, Nakhon Pathom 73170, Thailand

22

23

$24 *$ *Correspondence to: Narongrit Sombatsompop; E-mail: narongrit.som@kmutt.ac.th

25 Tel.: +66 2 470-8645; Fax: +66 2 470-8647

26 


\section{7 \\ ABSTRACT}

28

The mechanical and antibacterial properties of acrylic rubber/poly(methyl methacrylate) (AR/PMMA) blend at 10 to $50 \mathrm{wt} \%$ of AR content with non-treated and treated titanium dioxide $\left(\mathrm{TiO}_{2}\right)$ and 2-Hydroxypropyl-3-piperazinyl-quinoline carboxylic acid methacrylate (HPQM) by N-2(aminoethyl)-3-aminopropyl trimethoxysilane were studied. The antibacterial property against Escherichia coli was evaluated. The results found that the mechanical properties of $\mathrm{AR}^{\mathrm{t}-\mathrm{TiO} 2} / \mathrm{PMMA}$ and $\mathrm{AR}^{\mathrm{t}-\mathrm{HPQM}} / \mathrm{PMMA}$ blend were higher than that of 34 the $\mathrm{AR}^{\mathrm{TiO}} / \mathrm{PMMA}$ and $\mathrm{AR} \mathrm{HPQM}^{\mathrm{HPMMA}}$ blend. For antibacterial property, the $\mathrm{AR} \mathrm{HPQM}^{\mathrm{HPMMA}}$ and $\mathrm{AR}^{\mathrm{t}-\mathrm{HPQM}} / \mathrm{PMMA}$ blend could act as the antibacterial material, while the AR ${ }^{\mathrm{TiO}} / \mathrm{PMMA}$ blend did not show. However, the $\mathrm{AR}^{\mathrm{t}-\mathrm{TiO}} / \mathrm{PMMA}$ blend could inhibit bacterial cell growth with 10 to $30 \mathrm{wt} \%$ of $\mathrm{AR}$ content. The recommended compositions of $\mathrm{AR}^{\mathrm{t}-\mathrm{TiO}} / \mathrm{PMMA}$ blend, which improved both mechanical and antibacterial properties, were 10 to $30 \mathrm{wt} \%$ of $\mathrm{AR}$ and were 10 to $50 \mathrm{wt} \%$ of $\mathrm{AR}$ for $\mathrm{AR}$ t-HPQM/PMMA. Moreover, the UV radiation increased the antibacterial properties by the destruction of the interaction in treated $\mathrm{TiO}_{2}$ and HPQM and

41 improved the antibacterial performance of $\mathrm{AR}^{\mathrm{t}-\mathrm{TiO}} / \mathrm{PMMA}$ and $\mathrm{AR}^{\mathrm{t}-\mathrm{HPQM}} / \mathrm{PMMA}$ blend.

42 KEYWORDS: Acrylic rubber; Antibacterial performance; HPQM; Poly (methyl 43 methacrylate); Silane coupling agent; Titanium dioxide

\section{ABBREVIATIONS}

$46 \quad \mathrm{AR}^{\mathrm{TiO}} / \mathrm{PMMA}=\mathrm{AR} / \mathrm{PMMA}$ blend with non-treated $\mathrm{TiO}_{2}$

$47 \quad \mathrm{AR}^{\mathrm{HPQM}} / \mathrm{PMMA}=\mathrm{AR} / \mathrm{PMMA}$ blend with non-treated HPQM

$48 \mathrm{AR}^{\mathrm{t}-\mathrm{TiO} 2} / \mathrm{PMMA}=\mathrm{AR} / \mathrm{PMMA}$ blend with treated $\mathrm{TiO}_{2}$

$49 \mathrm{AR}^{\mathrm{t}-\mathrm{HPQM}} / \mathrm{PMMA}=\mathrm{AR} / \mathrm{PMMA}$ blend with treated HPQM 
Introduction

52

53

54

55

The toughened PMMA was produced by the addition with elastomer, including acrylic rubber (AR) (An et al., 2014; Lee et al., 2015), acrylonitrile butadiene styrene (ABS) (Haddadi et al., 2016), epoxidized natural rubber (ENR) (Nakason et al., 2004), and poly(acrylonitrileco-styrene) (ASA) (Cocco et al., 2013). The rubber phase adsorbed the impact energy and generated the plastic deformation in the polymer blend, resulting in the toughness of PMMA (Wang, Zhang, et al., 2019). The toughened PMMA can be used more widely than PMMA. The products from toughened PMMA, such as shower cabin, the cover sheet for sanitaryware, are often at risk of the bacteria accumulation on their surface. Therefore, the various additives, including titanium dioxide $\left(\mathrm{TiO}_{2}\right)$ (Alrahlah et al., 2018; Shen et al., 2019; Sodagar et al., 2016), zinc oxide ( $\mathrm{ZnO}$ ) (Sathya et al., 2019), chitosan (Tan et al., 2012), and 2-hydroxypropyl-3piperazinyl-quinoline carboxylic acid methacrylate (HPQM) (Tangudom et al., 2019), are needed in order to extend this application. HPQM is a inorganic antibacterial agent, which is nontoxic to the human body and non-endocrine disruptor. HPQM could inhibit the cell wall synthesis and the DNA synthesis, resulting in cell death (Microsciencetech, 2000). Our previous study (Tangudom et al., 2018) found that the mechanical properties of the $\mathrm{AR}^{\mathrm{TiO} 2} / \mathrm{PMMA}$ blend decreased with increasing $\mathrm{TiO}_{2}$ content due to the attraction between $\mathrm{TiO}_{2}$ aggregation by the van der Waals force. Studies have pointed out significant problems, including the reduced mechanical properties of AR/PMMA by the $\mathrm{TiO}_{2}$ agglomeration. Therefore, the diminished $\mathrm{TiO}_{2}$ agglomeration by surface treatment with the silane coupling agents was interested.

Silane coupling agents consist of the silica atom and functional group, which could interact with the both organic and inorganic components. Their functional group interacts with the hydroxyl group on the $\mathrm{TiO}_{2}$ surface (Ambrósio et al., 2016; Wang, Jiang, et al., 2019; Xiao et al., 2017). It developed the interaction between the polymer and $\mathrm{TiO}_{2}$ particles and generated 
76 the crosslinked interphase region (Sombatsompop \& Chaochanchaikul, 2005). Work by Xiao 77 et al. (2017) studied poly (dodecafluoroheptyl methacrylate) (PDFMA) filled with non-treated and treated $\mathrm{TiO}_{2}$ by 3-(trimethoxysilyl) propylmethacrylate. The results found that the dispersibility of treated $\mathrm{TiO}_{2}$ in PDFMA was better than that of the non-treated $\mathrm{TiO}_{2}$ due to the chemical interaction between treated $\mathrm{TiO}_{2}$ and PDFMA. The chemical interaction between $81 \mathrm{TiO}_{2}$ and silane coupling agent was investigated by Zhao et al. (2012), who claimed that the $\mathrm{TiO}_{2}$ and silane coupling agent could interact with each other through Ti-O-Si bonding. Occurrences of the good dispersibility and chemical bonding of treated $\mathrm{TiO}_{2}$ was claimed to improve the mechanical properties of the matrix. This claim was in good agreement with findings of Ambrósio et al. (2016), found that the treated $\mathrm{TiO}_{2}$ increased the mechanical properties of Polyamide11 (PA11) due to the improvement of the interfacial adhesion. Regarding the effect of antibacterial property, the non-treated $\mathrm{TiO}_{2}$ could generate the reactive oxygen species (ROS), producing $\mathrm{O}_{2}^{-}$, $\mathrm{HOO}^{*}$, and $\mathrm{HO}^{-}$in dark environment and $\mathrm{HO}^{\bullet}$ in $\mathrm{UV}$ environment (Gali et al., 2016). However, the effect of silane coupling agent on the mechanical and antibacterial properties of HPQM in the matrix is still not investigate.

Based on the literature review, the $\mathrm{TiO}_{2}$ particles have the hydroxyl group on their surface, which increased the $\mathrm{TiO}_{2}$ agglomeration. The $\mathrm{TiO}_{2}$ agglomeration caused stress concentration and reduced the performance of ROS generation, resulting in the reduction of mechanical and antibacterial properties. In the case of HPQM, according to our previous work (Tangudom et al., 2019), the functional group could interfere with the miscibility of the

96 AR and PMMA phase and decreased the mechanical property. Thus, the aim of this present 97 study was to enhance the mechanical and antibacterial properties of the AR/PMMA blend filled 98 with the surface treatment of $\mathrm{TiO}_{2}$ and HPQM by N-2(aminoethyl)-3-aminopropyl 99 trimethoxysilane or KBM603. As recommended by the previous study (Tangudom et al., 2018, 2019), the non-treated and treated of $\mathrm{TiO}_{2}$ and HPQM content blend was fixed at 1.5 parts per 
101 hundred (pph) in AR/PMMA blend and incorporated with AR phase for 10 to $50 \mathrm{wt} \%$. The 102 tensile properties and impact strength of AR/PMMA blend with non-treated and treated $\mathrm{TiO}_{2}$ 103 and HPQM were investigated. The antibacterial performance against Escherichia coli (ATCC 104 25922) was evaluated using the standard method of JIS Z2801:2010. The effect of UV radiation 105 exposure on the antibacterial performance was recognized.

\section{Materials and methods}

\section{Chemicals and materials}

Acrylic rubber (AR) grade AR 71 and poly (methyl methacrylate) (PMMA) grade 109 MD001 were supplied from Zeon Chemicals (Thailand) Co., Ltd. and Mitsubishi Rayon 110 Co., Ltd., respectively. The rutile titanium dioxide $\left(\mathrm{TiO}_{2}\right)$ particles acts as a carrier and an 111 antibacterial agent with an average primary particle size of $11.2 \mu \mathrm{m}$ which was acquired from 112 Chanjao Longevity Co., Ltd. A 2-hydroxypropyl-3-piperazinyl-quinoline carboxylic acid 113 methacrylate (HPQM) grade BA 101 as an antibacterial agent was kindly provided from 114 Koventure Co., Ltd. (10 wt\% of HPQM in solution) (Microsciencetech, 2000). $115 \mathrm{~N}$-2(aminoethyl)-3-aminopropyl trimethoxysilane $(\mathrm{Mw}=222.4)$ was used as the silane 116 coupling agent for $\mathrm{TiO}_{2}$ and HPQM, which applied from Shin-Etsu Chemical, Japan. The 117 antibacterial agents were treated by the silane coupling agent called N-2(aminoethyl)3118 aminopro-propyl trimethoxysilane (KBM603), which was supplied by Shin- Etsu Chemical 119 Co., Ltd. (Tokyo).

\section{Preparation treated $\mathrm{TiO}_{2}$ and $\mathrm{HPQM}$ by the silane coupling agent}

$\mathrm{TiO}_{2}$ particles were cleaned by sonication in deionized water for an hour to break up 122 any weakly flocculated particles and then dried in a hot-air oven at $60^{\circ} \mathrm{C}$ for $24 \mathrm{~h}$. After that, 123 the $\mathrm{TiO}_{2}$ and HPQM (10 wt $\%$ of HPQM in water) were added to a $1 \mathrm{wt} \%$ of $\mathrm{KBM} 603$ in toluene 
124 for $1 \mathrm{~h}$ and then dried at $60{ }^{\circ} \mathrm{C}$ for $48 \mathrm{~h}$. Then, the solution, as called a treated $\mathrm{TiO}_{2}$ and treated 125 HPQM was stirred at room temperature for $4 \mathrm{~h}$ at $50{ }^{\circ} \mathrm{C}$.

\section{Specimen preparation}

The blends were prepared by mixing acrylic rubber with non-treated and treated of $\mathrm{TiO}_{2}$ 128 and HPQM at 1.5 parts per hundred (pph), which was called "modified AR". The modified AR compounds at loadings from 10 to $50 \mathrm{wt} \%$ were then blended with PMMA via a melt blending 130 process using a twin-screw extruder at a mixing temperature of 200 to $230{ }^{\circ} \mathrm{C}$. The material 131 formulas are given in Table 1. Sheets of the blends for antibacterial performance testing were 132 prepared using a hot compression molding at an operating temperature of $230{ }^{\circ} \mathrm{C}$, a holding pressure of $15 \mathrm{~N} / \mathrm{mm}^{2}$, and an operating time of $15 \mathrm{~min}$. The sheets had a thickness of approximately $2 \mathrm{~mm}$. Sheets of the blends for mechanical properties testing were prepared using an injection molding machine. The samples were a dumbbell shape according to the 136 ISO 527-2:1993 standard.

\section{$U$ V radiation exposure}

The rectangle samples of the $\mathrm{AR}^{\mathrm{t}-\mathrm{TiO}_{2}} / \mathrm{PMMA}$ and $\mathrm{AR}^{\mathrm{t}-\mathrm{HPQM}} / \mathrm{PMMA}$ blends were exposed to UV radiation for $24 \mathrm{~h}$ using a QUV accelerated-weathering tester (Q-LAB, 140 Westlake, USA), in accordance with the ISO 4892-3:2016 standard procedure. The wavelength 141 of UV-A was $320-400 \mathrm{~nm}$ with an intensity of $0.77 \mathrm{~W} / \mathrm{m}^{2} / \mathrm{nm}$ at $50{ }^{\circ} \mathrm{C}$. These samples were 142 tested the antibacterial performance.

\section{Mechanical properties}

The mechanical properties, including impact strength, tensile toughness, tensile 145 modulus, tensile strength, and elongation at break of the AR/PMMA blends with non-treated 146 and treated of $\mathrm{TiO}_{2}$ and HPQM were tested. The notched impact strength was measured using 
147 a pendulum impact tester (5 joule) (HIT-5J, ZwickRoell, Germany), following the 148 ISO 179-1:2010 standard test method. Tensile testing was conducted according to the 149 ISO 527-2:1993 standard using a universal testing machine (Model H50kS, Tinius Olsen, UK). 150 The testing conditions were a gauge length of $50 \mathrm{~mm}$ and a crosshead speed of $50 \mathrm{~mm} / \mathrm{min}$. At 151 least five replicates were averaged for the reported value.

\section{Qualitative and quantitative determination of antibacterial performance}

The antibacterial performance of non-treated and treated $\mathrm{TiO}_{2}$ and HPQM of 154 AR/PMMA before and after UV radiation exposure against Escherichia coli (ATCC 25922) 155 was evaluated using the standard method of JIS Z2801:2010. The surface-sterilized specimens $(2.5 \times 2.5 \mathrm{~mm})$ were placed on sterilized Petri dishes. An inoculum of bacterial cell suspension in Nutrient Broth $(\mathrm{NB})$ at a cell turbidity of $\mathrm{OD}_{600} \sim 0.1$ was dropped onto the specimen surface and then covered with sterilized polypropylene film. After incubation at $37{ }^{\circ} \mathrm{C}$ for $24 \mathrm{~h}$, the bacterial cell suspension on the specimen surface was washed with $10 \mathrm{~mL}$ of Soya Casein Digest Lecithin Polysorbate (SCDLP) broth. Bacterial cell suspension in SCDLP was diluted in $0.85 \% \mathrm{NaCl}$ and the appropriate dilutions were spread on Nutrient Agar (NA) plates. After incubation at $37^{\circ} \mathrm{C}$ for $24 \mathrm{~h}$, the number of bacterial colonies appearing on the NA plates from 163 the specimens with $\left(\mathrm{N}_{\mathrm{i}}\right)$ and without $\mathrm{TiO}_{2}$ addition $\left(\mathrm{N}_{0}\right)$ was counted. The values of 164 antibacterial activity (R) of the blends were calculated by the following equation (1) (Chung et 165 al., 2007). greater than $99.9 \%$ bacterial reduction and the sample is accepted as an antibacterial material according to the standard of JIS Z2801:2010. 


\section{Results and discussion}

\section{Mechanical properties of AR/PMMA blends filled with non-treated and treated TiO ${ }_{2}$ and $172 \quad H P Q M$}

Fig. 1 shows the tensile properties of the AR/PMMA and AR/PMMA blends with 174 non-treated and treated $\mathrm{TiO}_{2}$. Fig. 1a shows that the addition of non-treated $\mathrm{TiO}_{2}$ decreased the 175 tensile strength of the AR/PMMA blend at 10 and $20 \mathrm{wt} \%$ of AR contents and the effect was 177 be related to the interference of the non-treated $\mathrm{TiO}_{2}$ on the interaction between $\mathrm{AR}$ and PMMA 178 phases. PMMA and AR phases could be compatible due to the dipole-dipole interaction 179 between the carbonyl group of PMMA and AR phase (Lommerse et al., 1998). Fig. 2 shows 180 the FTIR spectrum of PMMA, AR, and 50AR/PMMA blend. Fig. 2a shows the FTIR spectrum 181 of PMMA. The peaks at 2962, 2951, 2844, 1141, 1190 and $1238 \mathrm{~cm}^{-1}$ can be attributed to the stretching vibration mode of $-\mathrm{CH}_{3}, \quad-\mathrm{C}-\mathrm{H}$, $\quad-\mathrm{CH}_{2^{-}}$, $183-\mathrm{O}-\mathrm{CH}_{3}$, -C-O- and -C-O- (in carboxylic acid), respectively (Duan et al., 2008; Ramesh et al., 184 2007). The peaks at 1066, 986 and $841 \mathrm{~cm}^{-1}$ are the characteristic absorption vibration of 185 PMMA. The $\mathrm{C}-\mathrm{H}$ bonded bending of $\mathrm{CH}_{3}$ group is shows in peak at $1435 \mathrm{~cm}^{-1}$ (Duan et al., 186 2008). The two peaks at 1387 and $754 \mathrm{~cm}^{-1}$ can be assigned to the methylene group vibration 187 (Duan et al., 2008). The peak at $1722 \mathrm{~cm}^{-1}$ shows the presence of the acrylate carbonyl group 188 (Ramesh et al., 2007). The FTIR spectrum of AR is presented in Fig. 2b. The peak at 2985 $189 \mathrm{~cm}^{-1}$ represent the $\mathrm{C}-\mathrm{H}$ stretching vibration of $\mathrm{OCH}_{2} \mathrm{CH}_{3}$, while peak at 2934 represent the $\mathrm{CH}_{2}$ 190 stretching vibration of $\mathrm{OCH}_{2} \mathrm{CH}_{3}$ (Tangboriboon et al., 2008). Two peaks of 1446 and 1378 $191 \mathrm{~cm}^{-1}$ can be attributed to the $\mathrm{CH}_{3}$ asymatic deformation of $\mathrm{OCH}_{2} \mathrm{CH}_{3}$ and the peaks at 1247 192 and $1152 \mathrm{~cm}^{-1}$ represent C-O-C asymatric stretching vibration and R-C-O-R symmetric 193 stretching vibration, respectively (Tangboriboon et al., 2009). Two peaks of 1096 and 1022 
$194 \mathrm{~cm}^{-1}$ can be assigned to skeletal vibration of acrylic acid (Tangboriboon et al., 2008). The peak 195 at $1726 \mathrm{~cm}^{-1}$ shows the presence of the carbonyl group (Kader \& Bhowmick, 2000). However, 196 the functional groups of 50AR/PMMA blend similar to PMMA and AR, excepted the peak 197 represents the carbonyl group. It changed to $1725 \mathrm{~cm}^{-1}$ due to the weak bonding between 198 functional group. However, the change of proton of AR and PMMA was examined by the 199 chemical shift positions or $\delta$ values of ${ }^{1} \mathrm{H}-\mathrm{NMR}$ spectrum.

200

Fig. 3a-c shows the ${ }^{1} \mathrm{H}-\mathrm{NMR}$ spectrum of PMMA, AR, and 50AR/PMMA, 201 respectively. The assignments of peaks of protons and ${ }^{1} \mathrm{H}-\mathrm{NMR}$ spectra of PMMA are shown 202 in Fig. 3a (Wootthikanokhan et al., 1996). The methyl protons of PMMA (at b region) were 206 represented the isotactic PMMA structure (Rachellowe, 2017). Moreover, the $\delta$ values of 207 protons attached to the carbon atom in the main chain $\left(-\mathrm{CH}_{2}-\right)$ appeared at $1.732 \mathrm{ppm}$ (at a 208 region). In the case of the $\mathrm{AR}$, the protons which attached to oxygen atom (at $\mathrm{f}$ and $\mathrm{g}$ region) 209 appeared at $\delta 4.117$ and $\delta 1.249$, respectively (Kader \& Bhowmick, 2000). A proton opposite 210 with ethyloxy group was appeared at $\delta 2.291$. However, the $\delta$ values of proton attached to the 211 carbon atom in the main chain $\left(-\mathrm{CH}_{2}\right)$ appeared at $1.548 \mathrm{ppm}$ (at d region), as shown in 212 Fig. 3b (Kader \& Bhowmick, 2000). Considering the $\mathrm{H}^{1}$-NMR spectrum of 50AR/PMMA 213 blend (Fig. 3c), the $\delta$ values of proton attached to the carbon atom in the main chain shifted 214 from 1.732 ppm to 1.642 ppm for PMMA, while shifted from 1.548 ppm to $1.621 \mathrm{ppm}$ for AR. 215 According to the literature (Green, 1974; Kader \& Bhowmick, 2000; Soman \& Kelkar, 2009), 216 the change of FTIR and NMR spectra of AR, PMMA, and 50AR/PMMA blend could indicate 217 the interaction between PMMA and AR phase. Fig. 4 shows the possible interactions between 
218 AR and PMMA phases. The dipole-dipole interaction between carbonyl group of PMMA and 219 AR could form in 50AR/PMMA blend.

220

The addition of $\mathrm{TiO}_{2}$ in the AR/PMMA blend could disturb the interaction between $\mathrm{AR}$

221 and PMMA phases. The possible mechanism shows in Fig. 5a, the hydroxyl group on the $\mathrm{TiO}_{2}$ 222 could react with the carbonyl group of the AR phase. This claim was in good agreement with 223 the findings of Liu et al. (2003). They claimed that $\mathrm{TiO}_{2}$ could interfere with the interaction of poly(ethylene oxide) (PEO) and lithium tetrafluoroborate $\left(\mathrm{LiBF}_{4}\right)$ by the formation the 225 hydrogen bonding between ether atom of PEO and a hydroxyl group of $\mathrm{TiO}_{2}$. Moreover, the 226 non-treated $\mathrm{TiO}_{2}$ could form the agglomeration structure and act as stress concentration, caused the interference of impact force transfer (Elsaka et al., 2011; Tangudom et al., 2018; 228 Tanumiharja et al., 2000). According to our previous (Tangudom et al., 2019), the stress 229 concentration was diminished by the uniform distribution of $\mathrm{TiO}_{2}$ particles in the blend with 230 high AR content, resulting in the slight increase in the tensile strength with the addition of 30 231 to $50 \mathrm{wt} \%$ of $\mathrm{AR}$ contents. Considering the tensile strength of the $\mathrm{AR}^{\mathrm{t}-\mathrm{TiO}} / \mathrm{PMMA}$ blend, it 232 was higher than that of the AR $\mathrm{AR}^{\mathrm{TiO}} / \mathrm{PMMA}$ blend. Because the KBM603 molecules could 233 diminish the hydrophilic properties on the $\mathrm{TiO}_{2}$ surface (Huang et al., 2010; Xiao et al., 2017) 234 and form the chemical bonding with the AR phase, as shown in Fig. 5b. The silanol group of 235 KBM603 could interact with the hydroxyl group on non-treated $\mathrm{TiO}_{2}$ particle and the amino 236 group could interact with the chlorine reactive site of the AR chain, resulting in the increase of 237 tensile strength. Many studies have claimed that the rubber-filler interaction was enhanced by 238 the appropriate silane coupling agent (Bansod et al., 2015; Kapgate et al., 2014; Scotti et al., 239 2012; Wahba et al., 2013).

Fig. 1b and 1c show the percentage of elongation at break and tensile toughness of $241 \mathrm{AR} / \mathrm{PMMA}$ and AR/PMMA blend with non-treated and treated $\mathrm{TiO}_{2}$, respectively. Similar to 
242 the tensile strength in Fig. 1a, the elongation at break and tensile toughness of AR ${ }^{\mathrm{TiO}} / \mathrm{PMMA}$ 243 blend were lower than those of the AR/PMMA blend only at 10 and $20 \mathrm{wt} \%$ of AR content.

244 Because the dipole-dipole interaction of AR/PMMA blend was interfered by the non-treated $245 \mathrm{TiO}_{2}$. Moreover, the non-treated $\mathrm{TiO}_{2}$ could form the agglomeration structure and act as stress 246 concentration during the tensile test (Elsaka et al., 2011; Tanumiharja et al., 2000). However, 247 this interference was diminished in the blend with high AR contents (30-50 wt\%), as mentioned 248 earlier. The elongation at break and tensile toughness of the $\mathrm{AR}^{\mathrm{t}-\mathrm{TiO}} / \mathrm{PMMA}$ blend was higher 249 than that of the $\mathrm{AR}^{\mathrm{TiO}} / \mathrm{PMMA}$ blend. It was associated with the influence of the chemical 250 interaction in AR/PMMA blend by KBM603 molecule. AR and PMMA phase was compatible 251 by the polar interaction. Meanwhile, the macromolecule of the AR/PMMA phase was 252 connected by the treated $\mathrm{TiO}_{2}$. In other words, the treated $\mathrm{TiO}_{2}$ could form the chemical 253 bonding in the AR/PMMA blend, which was stronger than that of the polar bonding. This is 254 probably why the elongation at break and tensile toughness of the $\mathrm{AR}^{\mathrm{t}-\mathrm{TiO} 2} / \mathrm{PMMA}^{\mathrm{B}}$ blend was 255 higher than that of the $\mathrm{AR}^{\mathrm{TiO}} / \mathrm{PMMA}$ blend. Moreover, the KBM603 decreased the 256 agglomeration of $\mathrm{TiO}_{2}$ particle, resulting in decreasing of the stress concentration in 257 AR/PMMA blend (Carballeira \& Haupert, 2009).

Fig. 6a shows the tensile strength of AR/PMMA and AR/PMMA with non-treated and treated HPQM. It was observed that the tensile strength of the AR ${ }^{\mathrm{HPQM}} / \mathrm{PMMA}$ blend with 10 and $20 \mathrm{wt} \%$ of AR contents was lower than that of the AR/PMMA blend. Considering the chemical structure of the non-treated HPQM molecule, it has a amino group in the structure 262 (Eksirinimitr et al., 2016) as shown in Fig. 7a. The amino group could interact with the 263 carbonyl groups of the AR molecule via hydrogen bonding, which interfered the compatibility 264 between AR and PMMA phases. It would be noticed that the tensile strength of $\mathrm{AR}^{\mathrm{HPQM}} / \mathrm{PMMA}$ blend with 30 to $50 \mathrm{wt} \%$ of $\mathrm{AR}$ content was higher than that of the AR/PMMA blend, this being associated with the influence of the crosslink structure in AR phase by the 
267 reaction between HPQM solution and AR molecules (Tangudom et al., 2019). Regarding the

268 effect of treated HPQM, the tensile strength of AR ${ }^{\text {t-HPQM}} / \mathrm{PMMA}$ blend was higher than that of 269 the AR ${ }^{\mathrm{HPQM}} / \mathrm{PMMA}$ blend. Because the silanol group of the KBM603 molecule could interact 270 with the carboxylic salt of non-treated HPQM molecule (Habekost et al., 2013), as shown in 271 Fig. 7b. Moreover, the amino group of KBM603 could interact with the chlorine reactive site 272 of AR chain, as expected, caused the enhancement of tensile strength. The percentage of 273 elongation at break and tensile toughness of AR/PMMA and AR/PMMA blend with non274 treated and treated HPQM shown in Fig. 6b and $\mathbf{6 c}$, respectively. This suggests that the 275 elongation at break and tensile toughness of $\mathrm{AR}^{\mathrm{HPQM}} / \mathrm{PMMA}$ blend with 10 and $20 \mathrm{wt} \%$ of $\mathrm{AR}$ 276 content were lower than those of the AR/PMMA blend due to the interference of HPQM 277 molecules. According to our previous work (Tangudom et al., 2019), this interference was 278 diminished by the crosslink structure in AR phase by the reaction between HPQM and AR 279 molecules. Moreover, the addition of treated HPQM in AR/PMMA blend enhanced the 280 elongation at break and tensile toughness, due to the chemical interaction in AR/PMMA blend 281 by KBM603 molecule, as discussed earlier. Thus, it could be claimed that the KBM603 282 molecule acts as the silane coupling agent for $\mathrm{TiO}_{2}$ particle and HPQM molecules and the 283 crosslinker for AR/PMMA blend.

However, it was noticeable that the AR/PMMA blend with 10 and $20 \mathrm{wt} \%$ of AR 285 content with non-treated and treated $\mathrm{TiO}_{2}$ and HPQM shows the high tensile strength, but the 286 elongation at break and tensile toughness was low. Meanwhile, the tensile strength of 287 AR/PMMA blend with 30 to $50 \mathrm{wt} \%$ of AR content was low, but the elongation at break and 288 tensile toughness were high. The explanation of these results would be related to phase 289 reversion, which affected the properties of the AR/PMMA blend. The morphology of 290 AR/PMMA blend with low AR content was the AR dispersed in PMMA matrix phase 291 (Tangudom et al., 2018). Therefore, the properties of the AR/PMMA blend were controlled by 
292 the PMMA phase (high tensile strength, low elongation at break, and tensile toughness). 293 However, the AR/PMMA blend with high AR content (30 to $50 \mathrm{wt} \%$ of AR content) in 294 AR/PMMA blend changed the morphology to the co-continuous phase between AR and 295 PMMA. If so, it can be postulated that the properties of AR/PMMA blend with high AR content 296 were controlled by the AR phase. In other words, they were a rubber-like material, resulting in 297 the low tensile strength and the high elongation at break and tensile toughness. Our results 298 corresponded very well to the findings of Amoabeng et al. (Amoabeng et al., 2017) observed 299 the morphology of polyisobutylene (PIB) and polyethylene oxide (PEO) blend. They found 300 that the co-continuous phase of the PEO/PIB blend has occurred when adding equal or higher 301 than $30 \mathrm{wt} \%$ of PEO content. Moreover, the decreasing of the tensile properties of $302 \mathrm{AR}^{\mathrm{TiO}} / \mathrm{PMMA}$ and $\mathrm{AR} \mathrm{HPQ}^{\mathrm{HPM}} / \mathrm{PMM}$ blend as compared with AR/PMMA blend did not 303 pronounce with 30 to $50 \mathrm{wt} \%$ of AR content. The explanation for the AR ${ }^{\mathrm{TiO}} / \mathrm{PMMA}$ blend 304 relates to the uniform force transfer. According to our previous work (Tangudom et al., 2018), 305 the distribution of $\mathrm{TiO}_{2}$ particle in AR/PMMA blend at high AR content was more uniform 306 than that of the low content, which could regularly distribute force during the tensile test. In 307 the case of the AR ${ }^{\mathrm{HPQM}} / \mathrm{PMMA}$ blend, this would probably be caused by the chemical 308 interaction of the HPQM and AR phase. The amino group of HPQM molecule could interact 309 with the chlorine reactive site of AR phase and form the chemical interaction and form the 310 chemical interaction with the AR phase, resulting in the increase of tensile properties 311 (Tangudom et al., 2019).

Fig. 8a and 8b show the impact strength of AR/PMMA and AR/PMMA blends with 313 non-treated and treated of $\mathrm{TiO}_{2}$ and HPQM, respectively. The impact strength depends on the 314 energy consumption for damage PMMA and AR phase (Collyer, 1994; Thankappan Nair et al., 315 2015), which differs from the tensile toughness. It was seen that the impact strength of $316 \mathrm{AR}^{\mathrm{TiO}} / \mathrm{PMMA}$ was lower than that of the AR/PMMA blend. Because non-treated $\mathrm{TiO}_{2}$ particle 
317 did not compatible with the AR phase, caused the interference of the impact force transfer 318 (Tangudom et al., 2018). For the impact strength of the AR ${ }^{\mathrm{t}-\mathrm{TiO} 2} / \mathrm{PMMA}$ blend, it was higher 319 than that of the $\mathrm{AR}^{\mathrm{TiO}} / \mathrm{PMMA}$. It could be associated with the crosslinked structure in the AR 320 phase from treated- $\mathrm{TiO}_{2}$ could adsorb the impact force during the test. In the case of $321 \mathrm{AR} \mathrm{HPQM} / \mathrm{PMMA}$, the impact strength tended to be higher than that of AR/PMMA. According 322 to the earlier discussion, the amino group of the HPQM molecule could form the crosslinked 323 structure by the interaction with the chlorine reactive site group of the AR phase. If so, it can 324 be postulated that the impact force was adsorbed by their crosslink structure. However, the 325 impact strength of the $\mathrm{AR}^{\mathrm{t}-\mathrm{HPQM}} / \mathrm{PMMA}$ blend tends to be higher than that of the $326 \mathrm{AR} \mathrm{HPQM} / \mathrm{PMMA}$ blend. According to the scheme, as shown in Fig. 7b, the KBM603 molecule 327 could interact with chlorine reactive site of AR phase and form the crosslinked structure, which 328 adsorbed the impact force (Asaletha et al., 1999; Hesami \& Jalali-Arani, 2018; Jiang et al., 329 2014; Lee \& Han, 1999). The evidence, which investigated the interference of $\mathrm{TiO}_{2}$ and 330 HPQM, was the FTIR spectrum at the carbonyl group position. Fig. 9 shows the FTIR spectrum 331 of the 50AR/PMMA, 50AR $\mathrm{AR}^{\mathrm{TiO}} / \mathrm{PMMA}$, and 50AR ${ }^{\mathrm{HPQM}} / \mathrm{PMMA}$. The results show that the 332 FTIR spectrums of the carbonyl group of the 50AR/PMMA phase shift from $1723 \mathrm{~cm}^{-1}$ to $3331725 \mathrm{~cm}^{-1}$ of the 50AR $\mathrm{AR}^{\mathrm{TiO}} / \mathrm{PMMA}$, and $\mathrm{AR}^{\mathrm{HPQM}} / \mathrm{PMMA}$, which supported the occurrence of 334 the weak interaction between AR phase and the antibacterial agents $\left(\mathrm{TiO}_{2}\right.$ and $\left.\mathrm{HPQM}\right)$. It could 335 be concluded that the interference of the antibacterial agent decreased the compatibility 336 between PMMA and AR phases, and this resulted in the discontinuous force transfer during 337 the impact test. 
The quantitative antibacterial activities using $\mathrm{R}$ value of AR/PMMA blend with non341 treated and treated $\mathrm{TiO}_{2}$ and HPQM against the growth of E. coli using JIS Z2801 specifications 342 are given in Fig. 10. If the $\mathrm{R}$ value is equal to or higher than 2.0, bacterial reduction approaches $34399.9 \%$, and the sample is accepted as an antibacterial material (Association, 2010). It was seen 344 that the $\mathrm{AR}^{\mathrm{TiO}} / \mathrm{PMMA}$ blend did not act as the antibacterial material. However, the R-value of 345 the $\mathrm{AR}^{\mathrm{t}-\mathrm{TiO} 2} / \mathrm{PMMA}$ blend was higher than 2.0, as shown in Fig. 10a. Because the chemical 346 reaction of the $\mathrm{AR}$ phase and treated $\mathrm{TiO}_{2}$ particle established the large free volume between 347 the AR-PMMA molecule, which increased the flexibility in AR/PMMA blend. Work by 348 Gali et al. (2016) claimed that $\mathrm{TiO}_{2}$ could generate $\mathrm{O}_{2}^{-}, \mathrm{HOO}^{-}$, and $\mathrm{HO}^{-}$in the dark due to 349 dissolved oxygen. Thus, it can be speculated that the oxygen from the environment and 350 bacterial suspension could support the ROS generation from $\mathrm{TiO}_{2}$. Therefore, the ROS could 351 move to contact with bacteria cell by the free volume of the AR/PMMA blend. However, the $352 \mathrm{R}$ value of $\mathrm{AR}^{\mathrm{t}-\mathrm{TiO}} / \mathrm{PMMA}$ blend at 40 and $50 \mathrm{wt} \%$ of $\mathrm{AR}$ content slightly decreased. The 353 assumption of this result, the $\mathrm{TiO}_{2}$ particles were embedded under the sample surface. 354 Considering the morphology of AR/PMMA blend with low AR contents, 10 to $30 \mathrm{wt} \%$ in this 355 case, the AR was a dispersed phase in PMMA matrix (Tangudom et al., 2018). The treated $356 \mathrm{TiO}_{2}$ particles in the AR dispersed phase could interact with dissolve oxygen and generate ROS 357 to inhibit bacteria cell growth. Meanwhile, the co-continuous morphology demonstrated for the 358 AR/PMMA blend with high AR contents (40 and $50 \mathrm{wt} \%$ ). Some of treated $\mathrm{TiO}_{2}$ particles were 359 embedded underneath the sample, which reduced the interaction between $\mathrm{TiO}_{2}$ particles and 360 dissolve oxygen. Therefore, the inhibition of bacteria cell growth by ROS decreased. 361 Nevertheless, it was noted that the $\mathrm{R}$ value of $\mathrm{AR}^{\mathrm{t}-\mathrm{TiO} 2} / \mathrm{PMMA}$ blend after exposure to UV 362 radiation was higher than 2.0 and was higher than that of the $\mathrm{AR}^{\mathrm{TiO}} / \mathrm{PMMA}$. Because the 363 excess ROS was increased by the photocatalysis process from $\mathrm{TiO}_{2}$ particle. 
Fig. 10b shows the antibacterial activities of AR/PMMA blend with non-treated and 365 treated HPQM against the growth of E. coli. It was observed that the $\mathrm{R}$ value of $366 \mathrm{AR}^{\mathrm{HPQM}} / \mathrm{PMMA}$ and $\mathrm{AR}^{\mathrm{t}-\mathrm{HPQM}} / \mathrm{PMMA}$ blend was higher than 2.0. HPQM molecules are the 367 organic material which solutes in the water, and they could penetrate throughout the specimen 368 to contact with bacteria cell wall by the stress concentration gradian theory (Eksirinimitr et al., 369 2016; Tangudom et al., 2019). In the case of the effect of UV radiation, the $\mathrm{R}$ value of $370 \mathrm{AR}^{\mathrm{t}-\mathrm{HPQM}} / \mathrm{PMMA}$ blend was still higher than 2.0. Because the HPQM and KBM603 molecule 371 could form the weak polar interaction. After exposure to UV radiation, the polar interaction of 372 treated HPQM was destroyed, which supported the generation of HPQM molecule throughout 373 the specimen. It could be concluded that KBM603 recommended for treated in the $\mathrm{TiO}_{2}$ and 374 HPQM to improve the mechanical properties for all AR/PMMA content. Considering the 375 antibacterial performance of AR/PMMA blend, the treated $\mathrm{TiO}_{2}$ and HPQM by KBM603 376 recommended for the hygiene products which were exposed to UV radiation.

\section{Conclusions}

The addition of non-treated of $\mathrm{TiO}_{2}$ and HPQM decreased the mechanical properties of AR/PMMA blend, whereas the treated of $\mathrm{TiO}_{2}$ and HPQM by KBM603 in AR/PMMA blend increased. The treatment of $\mathrm{TiO}_{2}$ and HPQM increased the free volume and flexibility in 381 AR/PMMA blend due to the chemical reaction. The evidence provided by FTIR and ${ }^{1} \mathrm{H}-\mathrm{NMR}$.

382 Considering the antibacterial performance, the AR/PMMA blend with non-treated and treated 383 HPQM could act as the antibacterial material. Therefore, the AR ${ }^{\mathrm{t}-\mathrm{HPQM}} / \mathrm{PMMA}$ blend with 10 and $20 \mathrm{wt} \%$ of AR content was recommended for the sanitarywares, which demand the high tensile strength and toughness, such as the shower cabin. Meanwhile, the AR ${ }^{\mathrm{t}-\mathrm{HPQM}} / \mathrm{PMMA}$ 386 blend with 30 to $50 \mathrm{wt} \%$ of $\mathrm{AR}$ content was recommended for the cover sheet of the shower 387 bath, which need the high elongation during the processing. Meanwhile, the $\mathrm{AR}^{\mathrm{TiO}} / \mathrm{PMMA}^{\mathrm{N}}$ 
388 blend did not show the antibacterial performance, but the AR ${ }^{\mathrm{t}-\mathrm{TiO} 2} / \mathrm{PMMA}$ blend could inhibit 389 bacterial cell growth with 10 to $30 \mathrm{wt} \%$ of AR content. Therefore, the $\mathrm{AR}^{\mathrm{t}-\mathrm{TiO}} / \mathrm{PMMA}$ blend 390 with 10 to $30 \mathrm{wt} \%$ of AR content was recommended for the sanitarywares, which demand the 391 high tensile strength and toughness. Moreover, the treated $\mathrm{TiO}_{2}$ and HPQM by KBM603 392 recommended for the hygiene products which were exposed to UV radiation for all AR/PMMA 393 content.

\section{Conflict of interest}

395 The authors declare no conflict of interest.

\section{Acknowledgements}

The authors would like to thank the Office of the Higher Education Commission 398 (OHEC) under the National Research University (NRU) Program and the Thailand Research 399 Fund (TRF) under the Royal Golden Jubilee Ph.D. Program (PHD/0151/2557). The authors 400 are grateful to the College of Industrial Technology, King Mongkut's University of Technology 401 North Bangkok (KMUTNB), the Faculty of Environment and Resource Studies, Mahidol 402 University, and the Department of Materials, Loughborough University for supplying 403 laboratory facilities. 


\section{References}

406 Alrahlah, A., Fouad, H., Hashem, M., Niazy, A. A., \& AlBadah, A. (2018). Titanium Oxide $407\left(\mathrm{TiO}_{2}\right) /$ Polymethylmethacrylate (PMMA) Denture Base Nanocomposites: Mechanical, 408 Viscoelastic and Antibacterial Behavior. Materials (Basel), 11(7), 1-15. 409 http://doi.org.10.3390/ma11071096

410 Ambrósio, J. D., Balarim, C. V. M., \& De-Carvalho, G. B. (2016). Preparation, 411 Characterization, and Mechanical/Tribological Properties of Polyamide 11/Titanium 412 Dioxide Nanocomposites. Polymer Composites, 37(5), 1415-1424. 413 http://doi.org.10.1002/pc.23310

414 Amoabeng, D., Roell, D., Clouse, K. M., Young, B. A., \& Velankar, S. S. (2017). A 415 Composition-Morphology Map for Particle-Filled Blends of Immiscible Thermoplastic $416 \quad$ Polymers. Polymer, 119, 212-223. https://doi.org/10.1016/j.polymer.2017.04.009

417 An, J., Kang, B. H., Choi, B. H., \& Kim, H. J. (2014). Observation and Evaluation of Scratch 418 Characteristics of Injection-Molded Poly(methyl methacrylate) Toughened by Acrylic 419 Rubbers. Tribology International, 77(1), 32-42. http://doi.org.10.1016/j.triboint. 420 2014.04.011

421 Asaletha, R., Kumarana, M. G., \& Thoma, S. (1999). Thermoplastic Elastomers from Blends 422 of Polystyrene and Natural Rubber Morphology and Mechanical Properties. European 423 Polymer Journal, 35, 253-271. https://doi.org/10.1016/S0014-3057(98)00115-3

424 Association, J. S. (2010). JIS Z2801 Antibacterial products In Test for antibacterial activity 425 and efficacy (pp. 27). Japan: Japanese Standards Association. 
427 Bansod, N. D., Kapgate, B. P., Das, C., Basu, D., Debnath, S. C., Roy, K., \& Wiessner, S. 428 (2015). Controlled Growth of In Situ Silica in a NR/CR Blend by a Solution Sol-Gel 429 Method and the Studies of Its Composite Properties. RSC Advances, 5(66), 53559430 53568. http://doi.org. $10.1039 / \mathrm{c5ra08971a}$

431 Carballeira, P., \& Haupert, F. (2009). Toughening Effects of Titanium Dioxide Nanoparticles 432 on $\mathrm{TiO}_{2} /$ Epoxy Resin Nanocomposites. Polymer Composites(1), 1241-1246. 433 http://doi.org.10.1002/pc.20911

434 Chung, C. J., Lin, H. I., \& He, J. L. (2007). Antimicrobial Efficacy of Photocatalytic $\mathrm{TiO}_{2}$ 435 Coatings Prepared by Arc Ion Plating. Surface and Coatings Technology, 202(4-7), 436 1302-1307. http://doi.org.10.1016/j.surfcoat.2007.07.077

437 Cocco, D. R., De Carvalho, F. P., \& Felisberti, M. I. (2013). Structures and Morphologies 438 Olefin Situ-polymerized Blends of PMMA and ASA. Journal of Applied Polymer 439 Science, 130(1), 654-664. http://doi.org.10.1002/app.39188

440 Collyer, A. A. (1994). Rubber Toughened Engineering Plastics.Springer Science+Business $441 \quad$ Media Dordrecht

442 Duan, G., Zhang, C., Li, A., Yang, X., Lu, L., \& Wang, X. (2008). Preparation and 443 Characterization of Mesoporous Zirconia Made by Using a Poly (methyl methacrylate) 444 Template. Nanoscale Res Lett, 3(3), 118-122. http://doi.org.10.1007/s11671-008-9123$445 \quad 7$

446 Eksirinimitr, A., Wimolmala, E., Taptim, K., \& Sombatsompop, N. (2016). Effects of 447 Simulation Conditions on Antibacterial Performance of Polypropylene and Polystyrene 448 Doped with HPQM Antibacterial Agent. Polymer Testing, 55(1), 123-134. 449 http://doi.org.10.1016/j.polymertesting.2016.08.012 
450 Elsaka, S. E., Hamouda, I. M., \& Swain, M. V. (2011). Titanium Dioxide Nanoparticles

451

452

453

454

455

456

457

458

459

460

461

462

463

464

465

466

467

468

469

470

471
Addition to a Conventional Glass-Ionomer Restorative: Influence on Physical and Antibacterial Properties. Journal of Dentistry, 39(9), 589-598. http://doi.org.10.1016/ j.jdent.2011.05.006

Fujii, N., Miyauchi, T., Oda, T., Bhowmick, A. K., \& Saha, T. (2020). Influence of Fluoroacrylate Cure Site Monomer on the Thermal and Mechanical Properties of the Polyacrylic Ester Elastomer. Rubber Chemistry and Technology, 93(2), 395-413. http://doi.org.10.5254/rct.19.80440

Gali, N. K., Ning, Z., Daoud, W., \& Brimblecombe, P. (2016). Investigation on the Mechanism of Non-Photocatalytically $\mathrm{TiO}_{2}$-Induced Reactive Oxygen Species and Its Significance on Cell Cycle and Morphology. Journal of Applied Toxicology, 36(10), 1355-1363. http://doi.org.10.1002/jat.3341

Green, R. D. (1974). The Nature of C-H Hydrogen Bonding. In R. D. Green (Ed.), Hydrogen Bonding by C-H Groups (pp. 158-167). Willey.

Habekost, L. V., Camacho, G. B., Lima, G. S., Ogliari, F. A., Piva, E., \& Moraes, R. R. (2013). Properties of Particulate Resin-Luting Agents with Phosphate and Carboxylic Functional Methacrylates as Coupling Agents. Journal of Applied Polymer Science, 127(5), 3467-3473. http://doi.org.10.1002/app.37627

Haddadi, E., Choupani, N., \& Abbasi, F. (2016). Experimental investigation on the mixedmode fracture of rubber-toughened PMMA using essential work of fracture method. Engineering Fracture Mechanics, 162, 112-120. http://doi.org.10.1016/j.engfracmech. 2016.05.011 
472 Hesami, M., \& Jalali-Arani, A. (2018). Morphology Development Via Static Crosslinking of 473 (Polylactic acid/Acrylic rubber) as an Immiscible Polymer Blend. Macromolecular 474 Materials and Engineering, 303(3), 1700446. http://doi.org.10.1002/mame.201700446

475 Huang, L., Chen, K., Lin, C., Yang, R., \& Gerhardt, R. A. (2010). Fabrication and 476 Characterization of Superhydrophobic High Opacity Paper with Titanium Dioxide 477 478 Nanoparticles. Journal of Materials Science, 46(8), 2600-2605. http://doi.org.10.1007/ s10853-010-5112-1

479 Jiang, X., Xu, C., Wang, Y., \& Chen, Y. (2014). Polyvinylidene Fluoride/Acrylonitrile 480 Butadiene Rubber Blends Prepared Via Dynamic Vulcanization. Journal of 481 Macromolecular Science Part B Physics, 54(1), 58-70. http://doi.org.10.1080/0022 2348.2014.984577

483 Kader, M. A., \& Bhowmick, A. K. (2000). New Miscible Elastomer Blend from Acrylate 484 Rubber. Rubber Chemistry and Technology, 73(5), 889-901. http://doi.org.10.5254/ 1.3547627

Kapgate, B. P., Das, C., Basu, D., Das, A., Heinrich, G., \& Reuter, U. (2014). Effect of Silane 487 488 Integrated Sol-Gel Derived in Situ Silica on the Properties of Nitrile Rubber. Journal of Applied Polymer Science, 131(15), 40054. http://doi.org.10.1002/app.40531

489 Lee, B. H., Chang, Y. W., \& Lim, H. M. (2015). Preparation and Characterizations of 490 Polymethylmethacrylate (PMMA)/Acrylate Rubber (ACM) Blend for Light Diffuser 491 Applications. Elastomers and Composites, 50(1), 49-54. http://doi.org.10.7473/ec. 492 2015.50.1.049

493 Lee, J. K., \& Han, C. D. (1999). Evolution of Polymer Blend Morphology During 494 Compounding in an Internal Mixer. Polymer, 40, 6277-6296. https://doi.org/10.1016/ $495 \quad$ S0032-3861(99)00022-1 
496 Liu, Y., Lee, J. Y., \& Hong, L. (2003). Morphology, Crystallinity, and Electrochemical 497 Properties of In Situ Formed Poly(ethylene oxide) $/ \mathrm{TiO}_{2}$ Nanocomposite Polymer 498 Electrolytes. Journal of Applied Polymer Science, 89(1), 2815-2822. https://doi.org/10. 499 1002/app.12487

500 Lommerse, J. P. M., Pricce, S. L., \& Taylor, R. (1998). Hydrogen Bonding of Carbonyl, 501 Ether,and Ester Oxygen Atoms with Alkanol Hydroxyl Groups. Journal of 502 Computational Chemistry, 18(6), 757-774. https://doi.org/10.1002/(SICI)1096503 987X(19970430)18:6<757::AID-JCC3>3.0.CO;2-R

504 Microsciencetech. (2000, May 29). Technical data sheet : BCA101A0. Retrieved from Korea: 505 www.mst21.com

506 Nakason, C., Panklieng, Y., \& Kaesaman, A. (2004). Rheological and Thermal Properties of 507 Thermoplastic Naturak Rubbers Based on PMMA/EPDM Blends. Journal of Applied 508 Polymer Science, 92(6), 3561-3572 https://doi.org/10.1002/app.20384

509 Rachellowe. (2017,August 11). NMR of PMMA-tacticity and its determination through NMR. 510 Impact Solution. https://www.impact-solutions.co.uk/nmr-of-pmma/s

511 Ramesh, S., Leen, K. H., Kumutha, K., \& Arof, A. K. (2007). FTIR Studies of PVC/PMMA 512 Blend Based Polymer Electrolytes. Spectrochimica Acta. Part A: Molecular and 513 Biomolecular Spectroscopy, 66(4-5), 1237-1242. http://doi.org.10.1016/j.saa. 2006.06.012

515 Sathya, S., Murthy, P. S., Devi, V. G., Das, A., Anandkumar, B., Sathyaseelan, V. S., Doble, 516 M., \& Venugopalan, V. P. (2019). Antibacterial and Cytotoxic Assessment of Poly(methyl methacrylate) Based Hybrid Nanocomposites. Materials Science and Engineering. C: Materials for Biological Applications, 100, 886-896. https://doi.org/10.1016/j.msec.2019.03.053 
520 Scotti, R., Wahba, L., Crippa, M., D'Arienzo, M., Donetti, R., Santo, N., \& Morazzoni, F. 521

522

523 (2012). Rubber-Silica Nanocomposites Obtained by In Situ Sol-Gel Method: Particle Shape Influence on the Filler-Filler and Filler-Rubber Interactions. Soft Matter, 8(7), 2131-2143. http://doi.org.10.1039/c1sm06716h

524 Shen, S. C., Letchmanan, K., Chow, P. S., \& Tan, R. B. H. (2019). Antibiotic Elution and 525 526 527 Mechanical Property of $\mathrm{TiO}_{2}$ Nanotubes Functionalized PMMA-based Bone Cements. Journal of the Mechanical Behavior of Biomedical Materials, 91, 91-98. https://doi.org/10.1016/j.jmbbm.2018.11.020

528 Sodagar, A., Khalil, S., Kassaee, M. Z., Shahroudi, A. S., Pourakbari, B., \& Bahador, A. 529 530 531 532 (2016). Antimicrobial Properties of Poly (methyl methacrylate) Acrylic Resins Incorporated with Silicon Dioxide and Titanium Dioxide Nanoparticles on Cariogenic Bacteria. Journal of orthodontic science, 5(1), 7-13. http://doi.org.10.4103/22780203.176652

533 Soman, V. V., \& Kelkar, D. S. (2009). FTIR Studies of Doped PMMA - PVC Blend System. 534 Macromolecular Symposia, 277(1), 152-161. http://doi.org.10.1002/masy.200950319

535 Sombatsompop, N., \& Chaochanchaikul, K. (2005). Average Mixing Torque, Tensile and 536 Impact Properties, and Thermal Stability of Poly(vinyl chloride)/Sawdust Composites 537 538 with Different Silane Coupling Agents. Journal of Applied Polymer Science, 96(1), 213-221. http://doi.org.10.1002/app.21422

539 Tan, H., Peng, Z., Li, Q., Xu, X., Guo, S., \& Tang, T. (2012). The use of Quaternised Chitosan540 loaded PMMA to Inhibit Biofilm Formation and Downregulate the Virulence541 associated Gene Expression of Antibiotic-resistant Staphylococcus. Biomaterials, 542 33(2), 365-377. https://doi.org/10.1016/j.biomaterials.2011.09.084 
543 Tangboriboon, N., Sirivat, A., Kunanuruksapong, R., \& Wongkasemjit, S. (2009).

544

545

546

547 Tangboriboon, N., Sirivat, A., \& Wongkasemjit, S. (2008). Electrorheology and 548 549

551

552

553

554

555 Tangudom, P., Wimolmala, E., Prapagdee, B., \& Sombatsompop, N. (2019). Mechanical 556 Properties and Antibacterial Performance of PMMA Toughened with Acrylic Rubber 557 558 559 Containing 2-Hydroxypropyl-3-Piperazinyl-Quinoline Carboxylic Acid Methacrylate (HPQM) and HPQM Absorbed on TiO2 Particles. Polymer Testing, 79(1), 106023. http://doi.org.10.1016/j.polymertesting.2019.106023

Tanumiharja, M., Burrow, M. F., \& Tyas, M. J. (2000). Microtensile Bond Strengths of Glass Ionomer (Polyalkenoate) Cements to Dentine Using Four Conditioners. Journal of Dentistry for Children, 28(1), 6. http://doi.org.10.1016/s0300-5712(00)00009-9

563 Thankappan Nair, S., Vijayan, P. P., Xavier, P., Bose, S., George, S. C., \& Thomas, S. (2015). 564 565 566 Electrorheological Properties of Novel Piezoelectric Lead Zirconate Titanate $\mathrm{Pb}\left(\mathrm{Zr}_{0.5}, \mathrm{Ti}_{0.5}\right) \mathrm{O}_{3}$-acrylic Rubber Composite. Materials Science and Engineering: $C$, 29(6), 1913-1918. http://doi.org.10.1016/j.msec.2009.03.002

Characterization of Acrylic Rubber and Lead Titanate Composite Materials. Applied Organometallic Chemistry, 22(5), 262-269. http://doi.org.10.1002/aoc.1388

Radiation and $\mathrm{TiO}_{2}$ Loading on Mechanical and Antibacterial Performances. PolymerPlastics Technology and Engineering, 57(18), 1963-1976. http://doi.org.10.1080/ 03602559.2018 .1447131 
567 Wahba, L., D'Arienzo, M., Donetti, R., Hanel, T., Scotti, R., Tadiello, L., \& Morazzoni, F. 568 (2013). In Situ Sol-Gel Obtained Silica-Rubber Nanocomposites: Influence of the Filler Precursors on the Improvement of the Mechanical Properties. RSC Advances, 569

570 3(17), 5832-5844. http://doi.org.10.1039/c3ra22706e

571 Wang, J., Zhang, X., Jiang, L., \& Qiao, J. (2019). Advances in Toughened Polymer Materials 572 by Structured Rubber Particles. Progress in Polymer Science, 98. 573 http://doi.org.10.1016/ j.progpolymsci.2019.101160

574 Wang, L., Jiang, X., Wang, C., Huang, Y., Meng, Y., \& Shao, J. (2019). Titanium Dioxide 575 Grafted with Silane Coupling Agents and Its Use in Blue Light Curing Ink. Coloration 576 Technology, 1(1), 1-8. http://doi.org.10.1111/cote.12434

577 Wootthikanokhan, J., R, P. B., \& Chaplin, R. P. (1996). Effect of Acrylic Diblock Copolymer 578 upon Interfacial Adhesion. Journal of Applied Polymer Science, 62, 835-844. 579 https://doi.org/10.1002/(SICI)1097-4628(19961031)62:5<835::AID-APP16>3.0.CO; $2-\mathrm{R}$

581 Xiao, Z., Guo, P., \& Sun, N. (2017). Preparation, Thermostability, and Hydrophobic Properties 582 of $\mathrm{TiO}_{2} /$ Poly(dodecafluoroheptyl methacrylate) Nanocomposites. Journal of Applied 583 Polymer Science, 134(2), 44377. http://doi.org.10.1002/app.44377

584 Zhao, J., Milanova, M., Warmoeskerken, M. M. C. G., \& Dutschk, V. (2012). Surface 585 Modification of $\mathrm{TiO}_{2}$ Nanoparticles with Silane Coupling Agents. Colloids and 586 Surfaces A: Physicochemical and Engineering Aspects, 413(1), 273-279. 587 http://doi.org.10.1016/j.colsurfa.2011.11.033

\section{8}

589 
1 LIST OF TABLES

2

\begin{tabular}{|c|lc|}
\hline Table No. & & Table Captions \\
\hline Table 1 & Material formulas. & \\
\hline
\end{tabular}

4 LIST OF FIGURES

5

\begin{tabular}{|c|c|}
\hline Figure No. & Figure Captions \\
\hline Figure 1 & $\begin{array}{l}\text { Tensile properties of AR/PMMA (white) and AR/PMMA blends with non- } \\
\text { treated (black) and treated (gray) of } \mathrm{TiO}_{2} \text {; tensile strength, (b) percentage of } \\
\text { elongation at break, and (c) tensile toughness. }\end{array}$ \\
\hline Figure 2 & FTIR spectrum of (a) PMMA, (b) AR, and (c) 50AR/PMMA blend. \\
\hline Figure 3 & $\begin{array}{l}{ }^{1} \mathrm{H}-\mathrm{NMR} \text { spectrum of (a) PMMA, (b) AR, and (c) 50AR/PMMA blend in } \\
\text { deuterated chloroform D }\left(\mathrm{CDCl}_{3}\right) \text {. }\end{array}$ \\
\hline Figure 4 & Scheme of the interaction between AR and PMMA phases. \\
\hline Figure 5 & $\begin{array}{l}\text { Schematic of the interaction of (a) non-treated and (b) treated } \mathrm{TiO}_{2} \text { particle in } \\
\text { AR/PMMA blend. }\end{array}$ \\
\hline Figure 6 & $\begin{array}{l}\text { Tensile properties of AR/PMMA (white) and AR/PMMA blends with } \\
\text { non-treated (black) and treated (pattern) of HPQM; (a) tensile strength, } \\
\text { (b) percentage of elongation at break, and (c) tensile toughness. }\end{array}$ \\
\hline Figure 7 & $\begin{array}{l}\text { Schematic of the interaction of (a) non-treated and (b) treated HPQM molecule } \\
\text { in AR/PMMA blend. }\end{array}$ \\
\hline Figure 8 & $\begin{array}{l}\text { Impact strength of AR/PMMA (white) and AR/PMMA blends with non-treated } \\
\text { (black) and treated (pattern) of (a) } \mathrm{TiO}_{2} \text { and (b) HPQM. }\end{array}$ \\
\hline Figure 9 & $\begin{array}{l}\text { FTIR spectrum of } \mathrm{AR} / \mathrm{PMMA}, \mathrm{AR}^{\mathrm{TiO}} / \mathrm{PMMA} \text {, and } \mathrm{AR} \text { HPQM/PMMA in the } \\
\text { wavelength range of } 1500 \text { to } 2000 \mathrm{~cm}^{-1} \text {. }\end{array}$ \\
\hline Figure 10 & $\begin{array}{l}\text { Antibacterial performance of AR/PMMA blends against } E \text {. coli with non- } \\
\text { treated (black) and treated before (gray) and after (white-dot) exposure to UV } \\
\text { radiation; (a) } \mathrm{TiO}_{2} \text { and (b) HPQM. }\end{array}$ \\
\hline
\end{tabular}


7 Table 1 Material formulas.

\begin{tabular}{|c|c|c|c|c|c|}
\hline \multirow[b]{2}{*}{ Formula } & \multicolumn{5}{|c|}{ Composition } \\
\hline & $\begin{array}{c}\text { PMMA } \\
(w t \%)\end{array}$ & $\begin{array}{c}\text { AR } \\
(\mathrm{wt} \%)\end{array}$ & $\begin{array}{l}\mathrm{TiO}_{2} \\
\text { (pph) }\end{array}$ & $\begin{array}{c}\text { HPQM } \\
\text { (pph) }\end{array}$ & $\begin{array}{c}\text { KBM603 } \\
(\%)\end{array}$ \\
\hline 10AR/PMMA & \multirow{5}{*}{90} & \multirow{5}{*}{10} & - & - & - \\
\hline $10 \mathrm{AR}^{\mathrm{TiO}_{2} / \mathrm{PMMA}}$ & & & 1.5 & - & - \\
\hline 10AR ${ }^{\mathrm{HPQM}} / \mathrm{PMMA}$ & & & - & 1.5 & - \\
\hline $10 \mathrm{AR}^{\mathrm{t}-\mathrm{TiO}_{2} / \mathrm{PMMA}}$ & & & 1.5 & - & 1 \\
\hline 10AR ${ }^{\mathrm{t}-\mathrm{HPQM}} / \mathrm{PMMA}$ & & & - & 1.5 & 1 \\
\hline 20AR/PMMA & \multirow{5}{*}{80} & \multirow{5}{*}{20} & - & - & - \\
\hline $20 \mathrm{AR}^{\mathrm{TiO}_{2} / \mathrm{PMMA}}$ & & & 1.5 & - & - \\
\hline 20AR $\mathrm{HPQM} / \mathrm{PMMA}$ & & & - & 1.5 & - \\
\hline $20 \mathrm{AR}^{\mathrm{t}-\mathrm{TiO}_{2} / \mathrm{PMMA}}$ & & & 1.5 & - & 1 \\
\hline 20AR $\mathrm{ARPM}^{\mathrm{t}-\mathrm{PMMA}}$ & & & - & 1.5 & 1 \\
\hline 30AR/PMMA & \multirow{5}{*}{70} & \multirow{5}{*}{30} & - & - & - \\
\hline $30 \mathrm{AR}^{\mathrm{TiO}_{2} / \mathrm{PMMA}}$ & & & 1.5 & - & - \\
\hline 30AR $\mathrm{HPQM} / \mathrm{PMMA}$ & & & - & 1.5 & - \\
\hline $30 \mathrm{AR}^{\mathrm{t}-\mathrm{TiO}_{2} / \mathrm{PMMA}}$ & & & 1.5 & - & 1 \\
\hline 30AR ${ }^{\mathrm{t}-\mathrm{HPQM}} / \mathrm{PMMA}$ & & & - & 1.5 & 1 \\
\hline 40AR/PMMA & \multirow{5}{*}{60} & & - & - & - \\
\hline $40 \mathrm{AR}^{\mathrm{TiO}_{2} / \mathrm{PMMA}}$ & & & 1.5 & - & - \\
\hline 40AR $\mathrm{HPQM} / \mathrm{PMMA}$ & & 40 & - & 1.5 & - \\
\hline $40 \mathrm{AR}^{\mathrm{t}-\mathrm{TiO}_{2} / \mathrm{PMMA}}$ & & & 1.5 & - & 1 \\
\hline 40AR ${ }^{\mathrm{t}-\mathrm{HPQM}} / \mathrm{PMMA}$ & & & - & 1.5 & 1 \\
\hline 50AR/PMMA & \multirow{5}{*}{50} & \multirow{5}{*}{50} & - & - & - \\
\hline $50 \mathrm{AR}^{\mathrm{TiO}_{2} / \mathrm{PMMA}}$ & & & 1.5 & - & - \\
\hline 50AR $\mathrm{HPQM} / \mathrm{PMMA}$ & & & - & 1.5 & - \\
\hline $50 \mathrm{AR}^{\mathrm{t}-\mathrm{TiO}_{2} / \mathrm{PMMA}}$ & & & 1.5 & - & 1 \\
\hline 50AR ${ }^{\mathrm{t}-\mathrm{HPQM}} / \mathrm{PMMA}$ & & & - & 1.5 & 1 \\
\hline
\end{tabular}



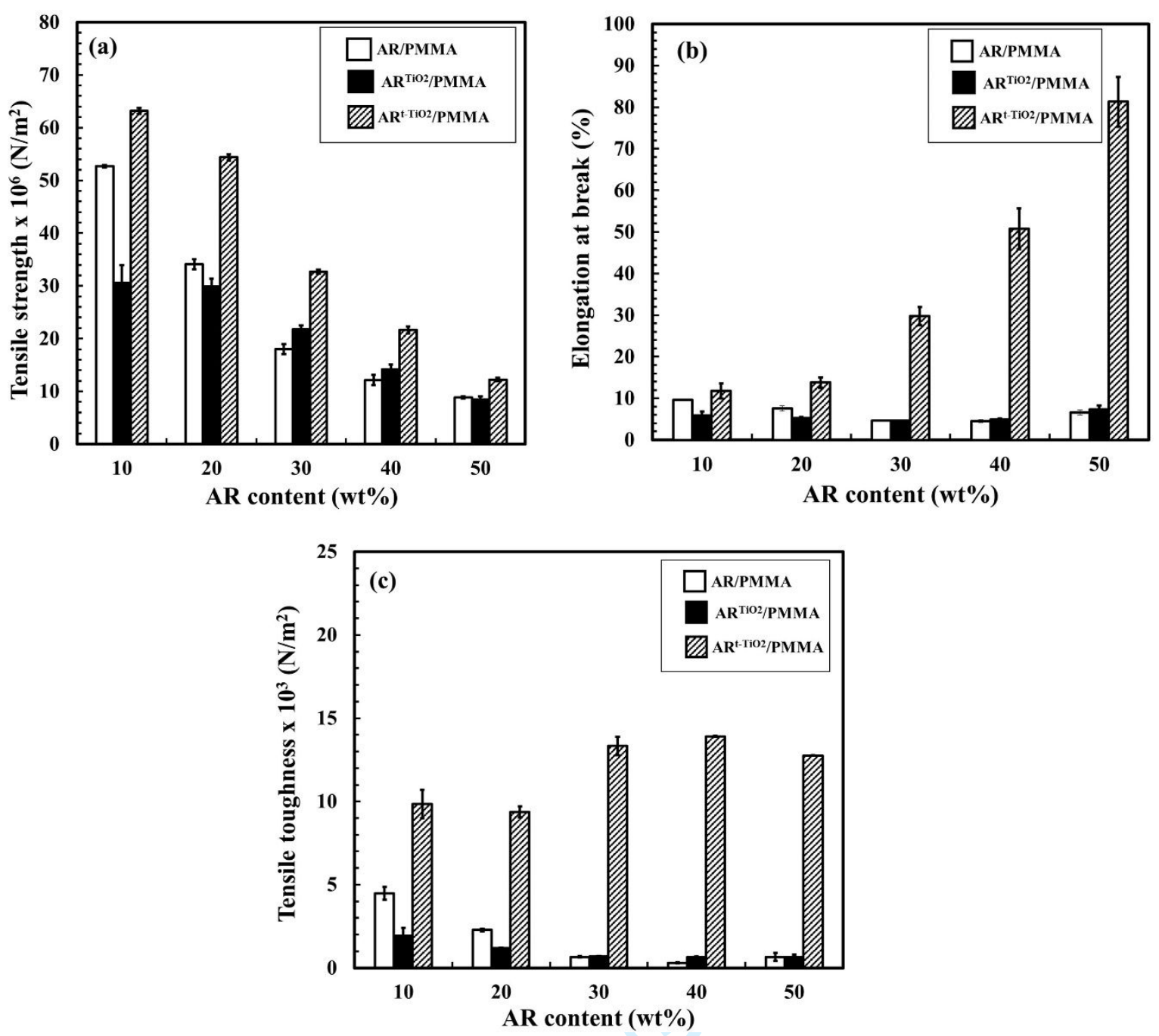

Figure 1 Tensile properties of AR/PMMA (white) and AR/PMMA blends with non-treated (black) and treated (pattern) of $\mathrm{TiO}_{2}$;

(a) tensile strength, (b) percentage of elongation at break, and (c) tensile toughness. 

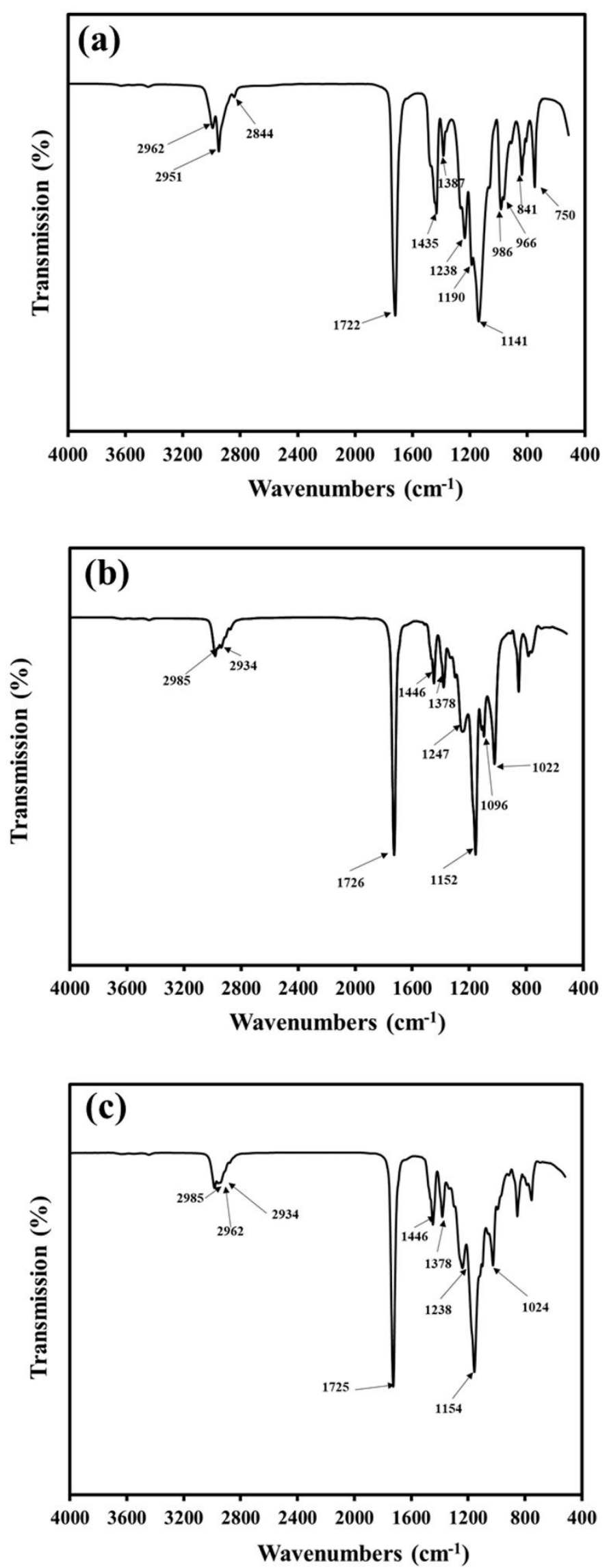

Figure 2 FTIR spectrum of (a) PMMA, (b) AR, and (c) 50AR/PMMA blend. 
(a)

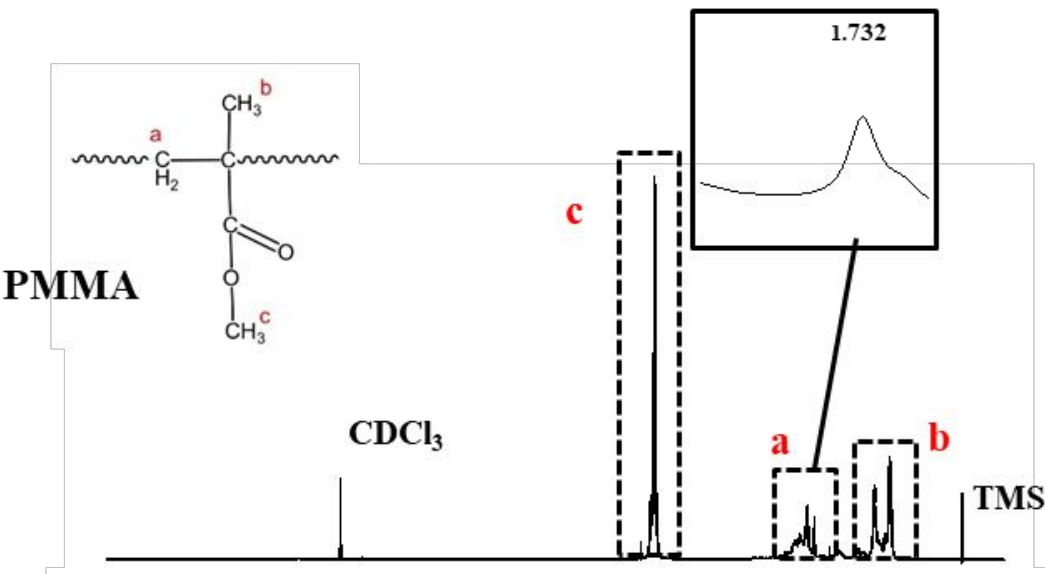

(b)

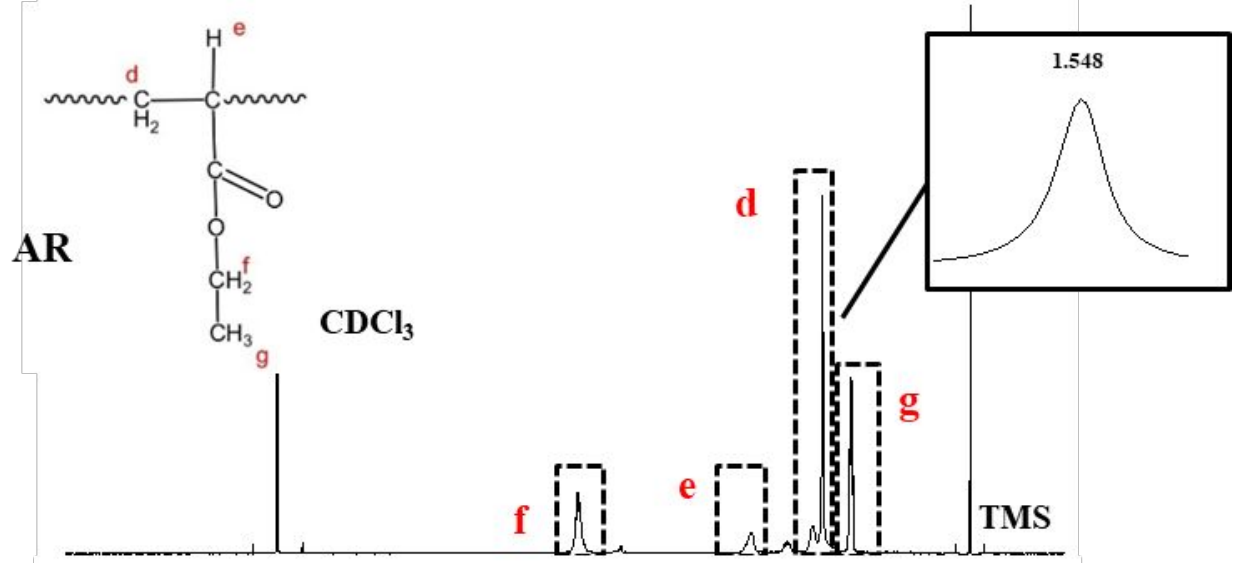

(c)
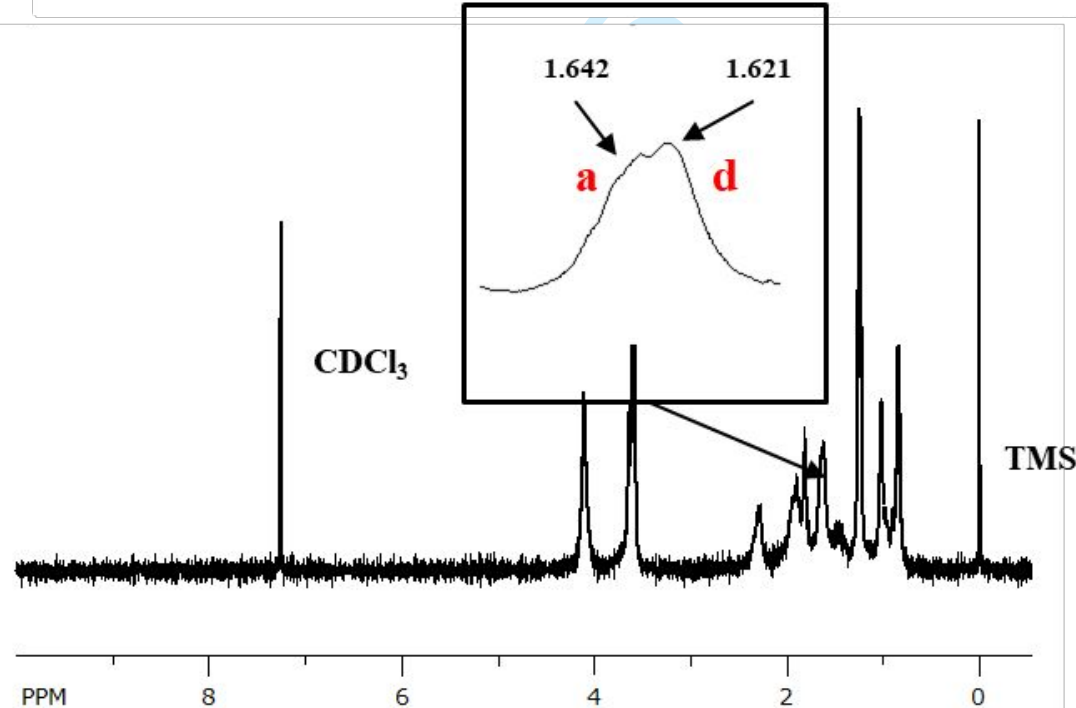

Figure $3{ }^{1} \mathrm{H}-\mathrm{NMR}$ spectrum of (a) PMMA, (b) AR, and (c) 50AR/PMMA blend in deuterated chloroform $\mathrm{D}\left(\mathrm{CDCl}_{3}\right)$. 


\section{dipole-dipole interaction}

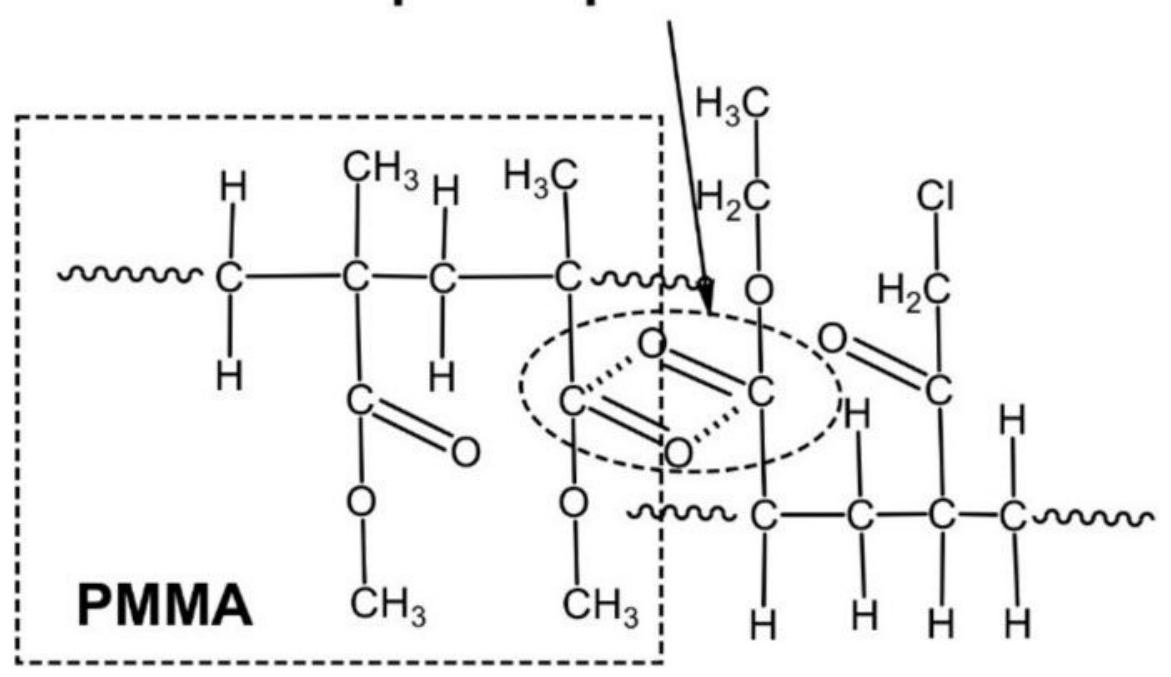

AR

Figure 4 Scheme of the interaction between AR and PMMA phases 
(a)

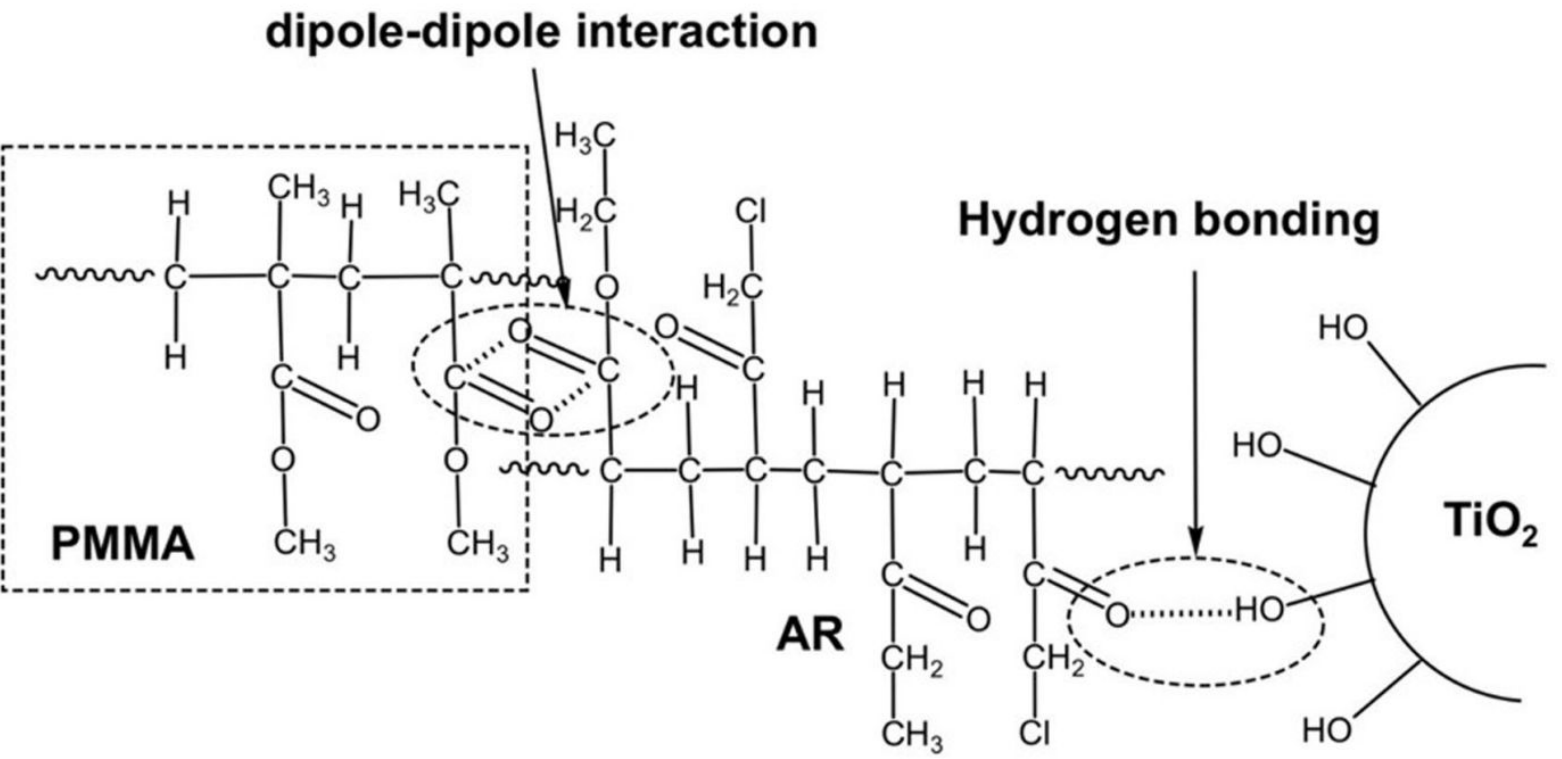

(b)

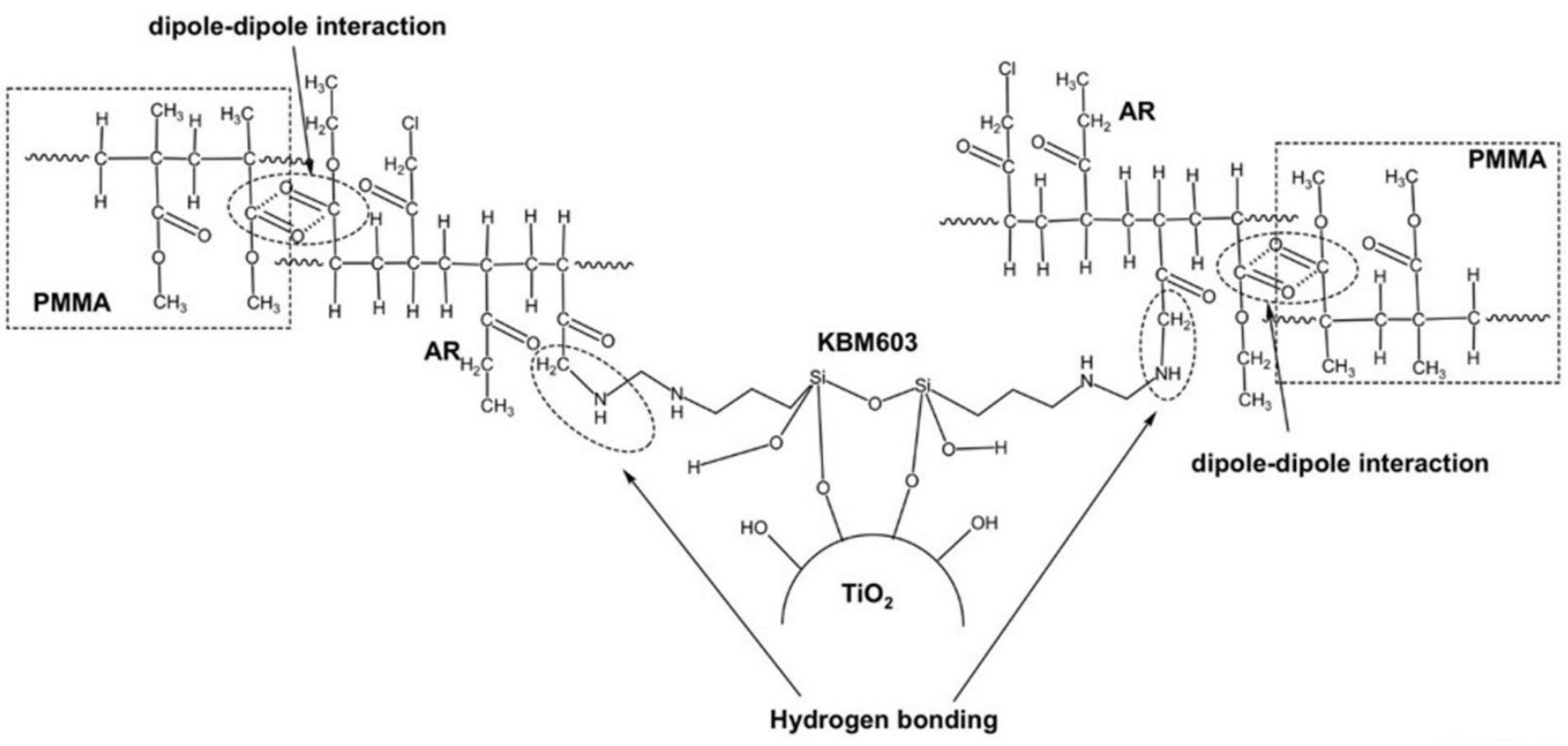

Figure 5 Schematic of the interaction of (a) non-treated and (b) treated $\mathrm{TiO}_{2}$ particle in AR/PMMA blend. 

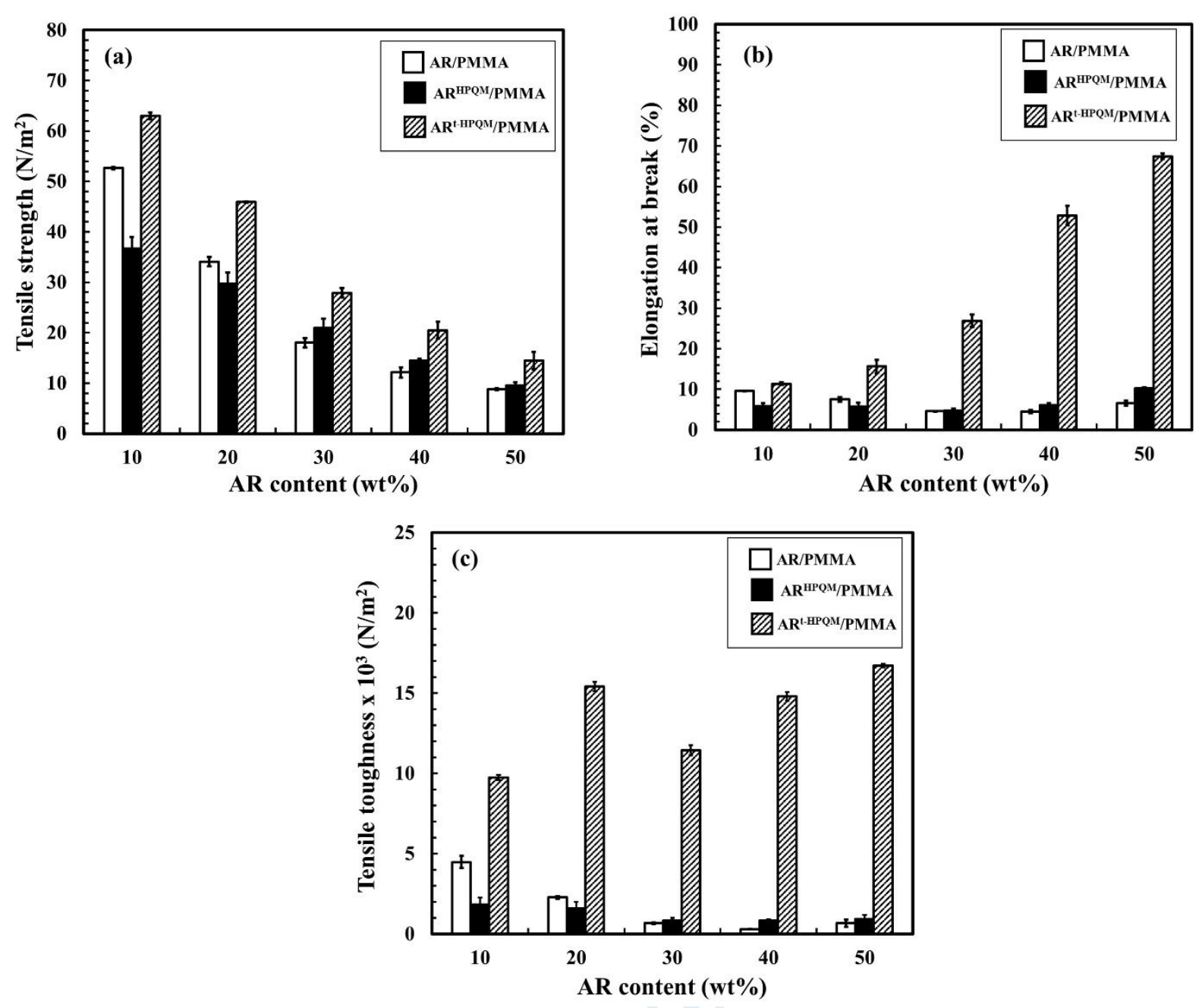

Figure 6 Tensile properties of AR/PMMA (white) and AR/PMMA blends with non-treated (black) and treated (pattern) of HPQM; (a) tensile strength, (b) percentage of elongation at break, and (c) tensile toughness. 
(a)

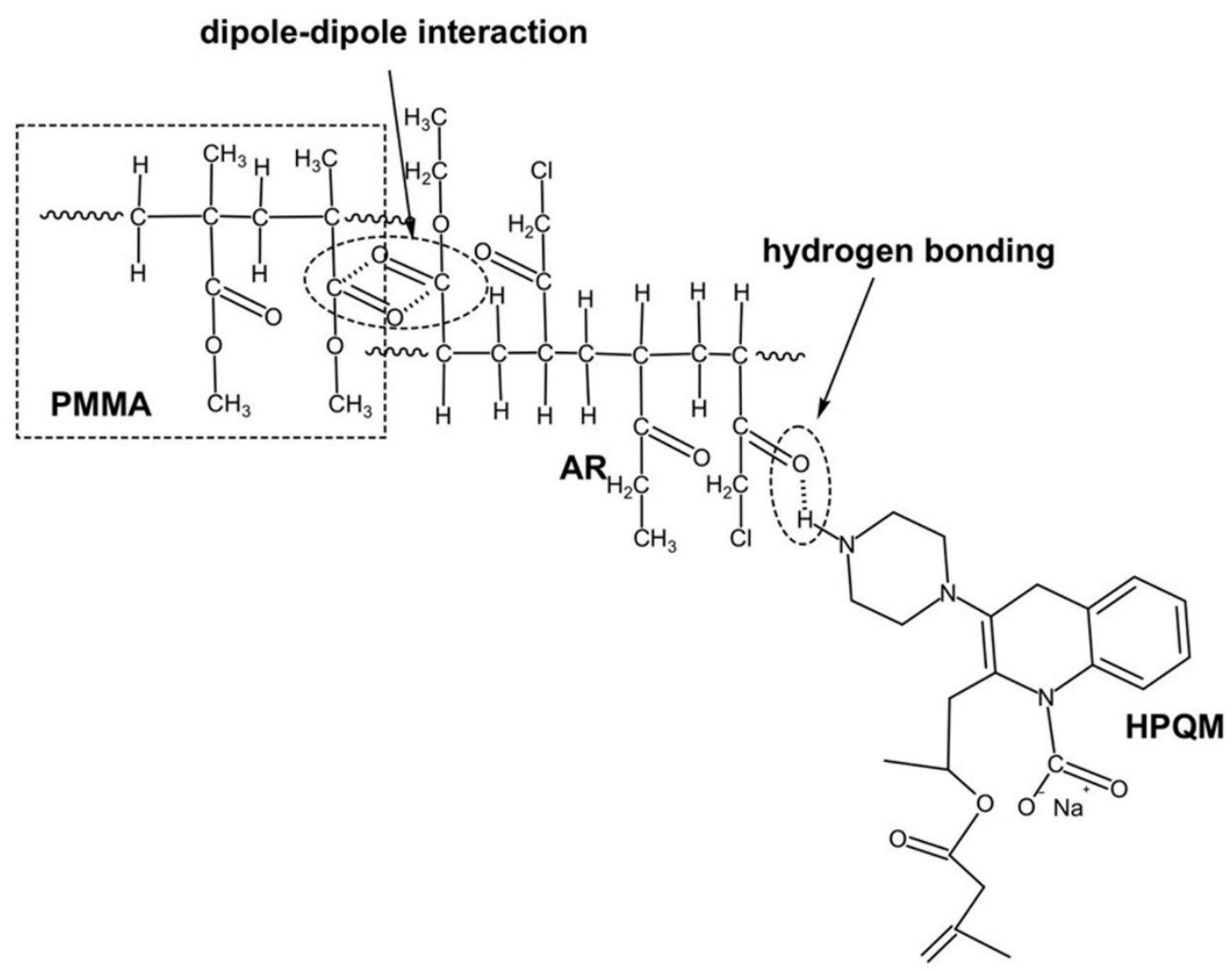

(b)

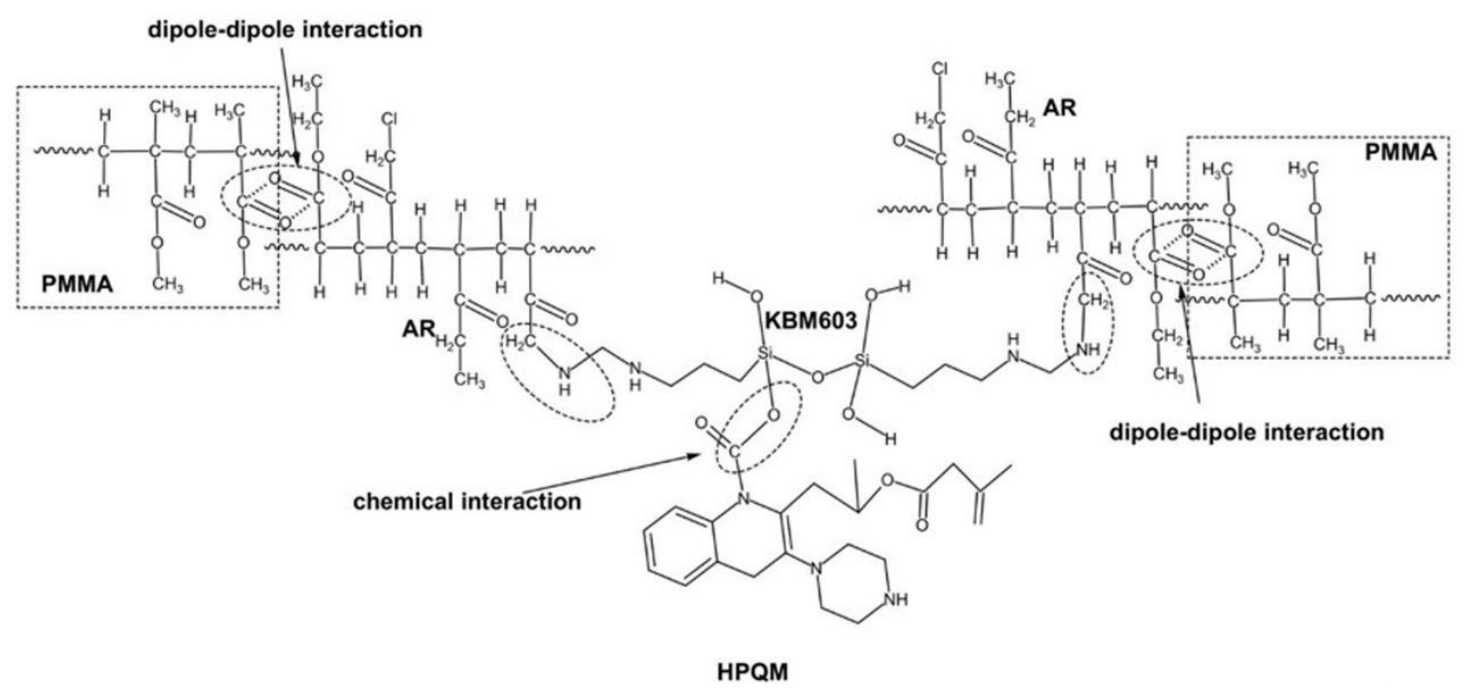

Figure 7 Schematic of the interaction of (a) non-treated and (b) treated HPQM molecule in AR/PMMA blend. 

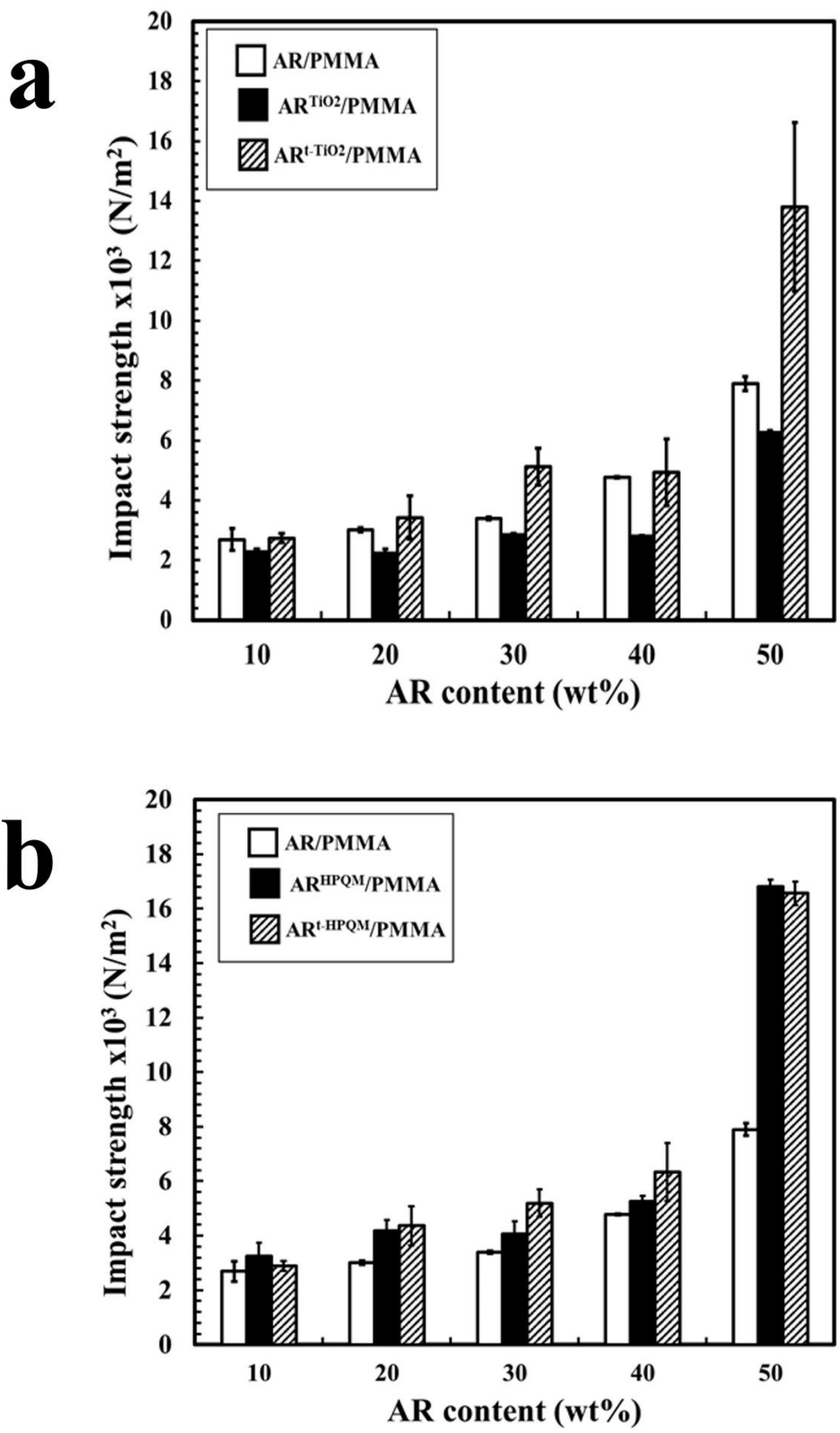

Figure 8 Impact strength of AR/PMMA (white) and AR/PMMA blends with non-treated (black) and treated (pattern) of (a) $\mathrm{TiO}_{2}$ and (b) HPQM. 
Journal of Reinforced Plastics and Composites

Page 38 of 38

$$
\begin{aligned}
& 1 \\
& 2 \\
& 3 \\
& 4 \\
& 5 \\
& 6 \\
& 7 \\
& 8 \\
& 9 \\
& 10 \\
& 11 \\
& 12 \\
& 13 \\
& 14 \\
& 15 \\
& 16 \\
& 17 \\
& 18 \\
& 19 \\
& 20 \\
& 21 \\
& 22 \\
& 23 \\
& 24 \\
& 25 \\
& 26 \\
& 27 \\
& 28 \\
& 29 \\
& 30 \\
& 31 \\
& 32 \\
& 33 \\
& 34 \\
& 35 \\
& 36 \\
& 37 \\
& 38 \\
& 39 \\
& 40 \\
& 41 \\
& 42 \\
& 43 \\
& 44 \\
& 45 \\
& 46 \\
& 47 \\
& 48 \\
& 49 \\
& 50 \\
& 51 \\
& 52 \\
& 53 \\
& 54 \\
& 55 \\
& 56 \\
& 57 \\
& 58 \\
& 59
\end{aligned}
$$

Figure 9 FTIR spectrum of $\mathrm{AR} / \mathrm{PMMA}, \mathrm{AR}^{\mathrm{TiO} 2} / \mathrm{PMMA}$, and $\mathrm{AR}{ }^{\mathrm{HPQM}} / \mathrm{PMMA}$ in the wavelength range of 1500 to $2000 \mathrm{~cm}^{-1}$.

https://mc.manuscriptcentral.com/jrpc 

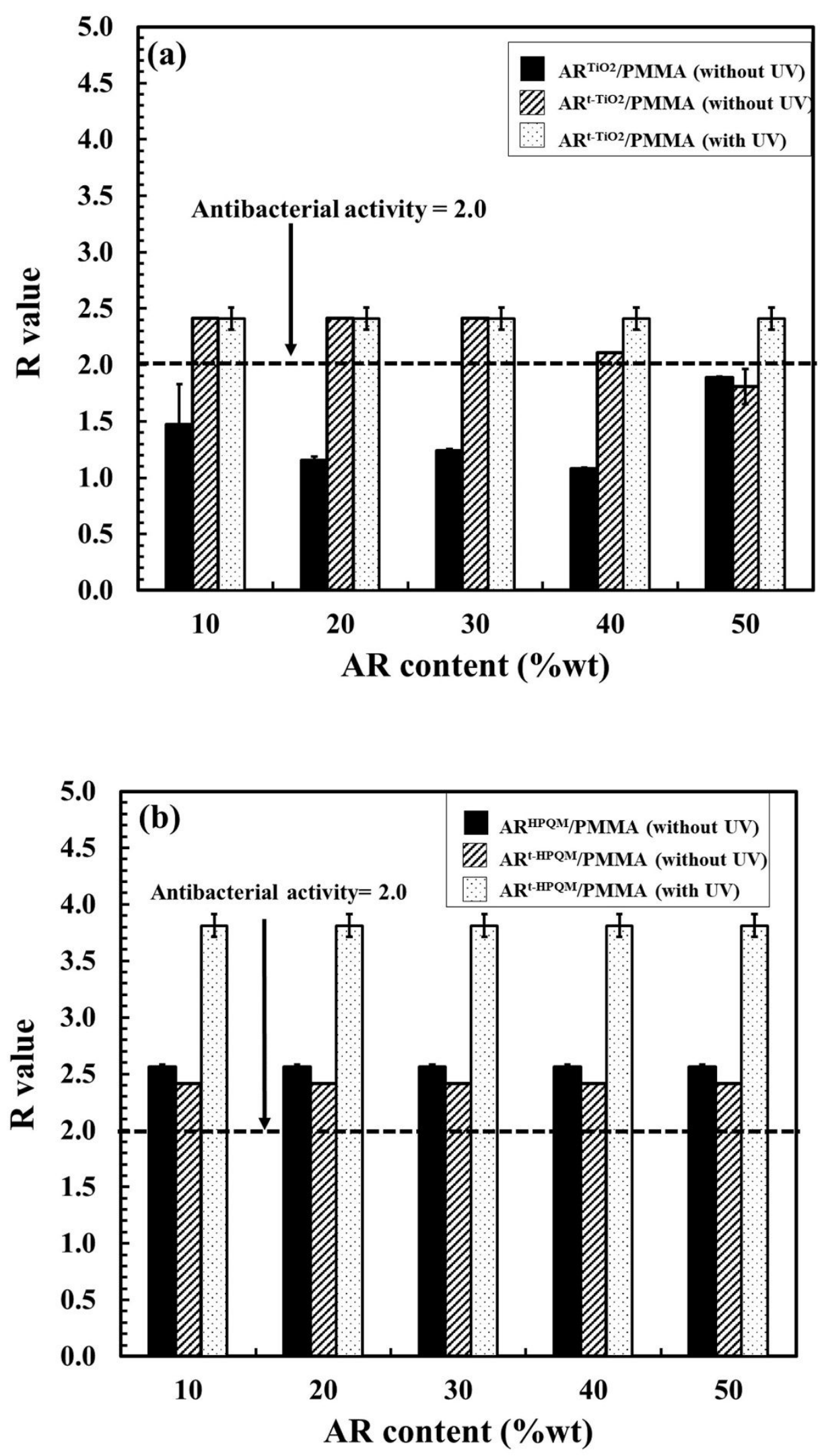

Figure 10 Antibacterial performance of AR/PMMA blends against E. coli with non-treated (black) and treated before (gray) and after (white-dot) exposure to UV radiation; (a) $\mathrm{TiO}_{2}$ and (b) HPQM. 